\title{
CUMPLIR O EJECUTAR. LA EJECUCION DE SENTENCIAS DEL TRIBUNAL CONSTITUCIONAL Y SU RECIENTE REFORMA
}

\author{
IGNACIO VILLAVERDE MENÉNDEZ \\ Catedrático de Derecho Constitucional \\ Universidad de Oviedo
}

\section{SUMARIO}

I. Alguna cuestión previa. II. La reforma de la LOTC por la LO 15/2015, de 16 de octubre, para la ejecución de las resoluciones del Tribunal Constitucional como garantía del Estado de Derecho. Un breve comentario. III. El primer caso de aplicación de la reforma: el ATC 141/2016, de 19 de julio y actuaciones subsiguientes. IV. El incidente de ejecución. V. LA doctrina del TC sobre el incidente de ejecución del artículo 92 LOTC. VI. La posición del TC a través del incidente de ejecución. VII. La constitucionalidad de la reforma del incidente de ejecución.

\section{ALGUNA CUESTIÓN PREVIA}

En el número 209 de la revista Documentación Administrativa de 1987 publicaban Javier Salas y Valeriano Palomino un artículo único y pionero en su género en España, hasta donde se nos alcanza, «La ejecución de sentencias del Tribunal Constitucional» ${ }^{1}$. No se ha escrito nunca más sobre esta cuestión con ese detenimiento. Ha diferencia de otras doctrinas, la ejecución de las resoluciones del TC no ha sido un tema del que se haya ocupado la academia constitucional o procesal, de hecho a penas le ha dedicado unas líneas². Quizá porque

1 Salas, J. Palomino, V., «La ejecución de las Sentencias del Tribunal Constitucional (Especial referencia a las relativas a la Administración)», $D A$, n. $^{\circ} 209,1987$, pp. 89 y ss.

2 Véase el espacio que le dedica CaAmaño/Gómez/Medina/Requejo, Jurisdicción y procesos constitucionales, Mcgraw hill, Madrid, 1997; Pérez Tremps, P., Sistema de justicia constitucional, Civitas, Madrid, 2010; Huelin Martínez de Velasco, J., Comentario a los artículos 80, 87 y 92, Comentarios a la Ley Orgánica del Tribunal Constitucional, Requejo Pagés, J. (coord.), TC/BOE, Madrid, 2001. Lo que 
el concepto procesal de ejecución de resoluciones jurisdiccionales se ha percibido ajeno a la dogmática de la justicia constitucional y del derecho procesal constitucional. Quizá porque en su condición de decisiones en gran medida declarativas, se ha tenido la creencia de que las resoluciones del Tribunal Constitucional (en adelante, TC) se cumplen, no se ejecutan. Por lo demás, la ejecución de las resoluciones del TC no ha sido, al menos en apariencia, una cuestión problemática ${ }^{3}$. Todo ello, a pesar de que un elemento crucial de la posición del TC en el sistema constitucional es, justo, la forma en la que se cumplen sus resoluciones.

Este concepto durmiente, la ejecución de resoluciones del TC, ha despertado de su letargo con ocasión de la Ley Orgánica 15/2015, de 16 de octubre, de reforma de la Ley Orgánica 2/1979, de 3 de octubre, del Tribunal Constitucional (en adelante LOTC), para la ejecución de las resoluciones del Tribunal Constitucional como garantía del Estado de Derecho (en adelante, LORLOTC) 4 . Los preceptos reformados han sido los artículos 80, 87, 92 y 95.4 LOTC.

Este artículo no pretende ensayar un remedo de dogmática de la ejecución de las resoluciones del TC, que bien merece un trabajo de más aliento que el que sostiene estas páginas. El lector que se abisme en ellas encontrará más bien una panoplia de dudas e incógnitas que suscita esta atropellada reforma de la LOTC, y que, si bien ha servido para volver nuestra vista a este extremo inadvertido del derecho procesal constitucional, lo ha hecho con algunas sombras. En primer lugar examinaremos la reforma y el trámite de la ejecución de las resoluciones del TC tal cual ha quedado regulado tras su modificación. Seguidamente se analizará el primer caso de aplicación del artículo 92 LOTC y, a resultas de todo ello, la jurisprudencia del TC sobre la ejecución de sus decisiones. Finalmente abordaremos muy someramente la posición del TC tras esta reforma y sus consecuencias sistémicas, entre ellas la constitucionalidad de la propia reforma.

contrasta con la nutrida literatura que ha comentado esta cuestión y en particular el alcance de los poderes de ejecución del BVerfG con arreglo al $\$ 35$ de la Ley reguladores del Tribunal Constitucional Federal alemán (BVerfGG). Por todos y los allí citados BETHGE, H., § 35 BVerfGG Kommentar, Bundesferfassungsgerichtsgesetz. Kommentar, Maunz/Schmidt-Bleibetreu/Klein/Bethge, C.H.Beck, München (Lfg.44, julio 2014). Recientemente, Almeida Cerreda, M., «El nuevo sistema de ejecución de las resoluciones del Tribunal Constitucional español», Istituzioni dei Federalismo n. ${ }^{\circ} 371$, pp. 163-189.

3 Según consta en sus Memoria el TC ha resuelto en sus 35 años apenas medio centenar de incidentes de ejecución en relación con sus resoluciones. Una media de menos de 2 al año (destacando el 2001 con 7 y el 2008 con 5). Un escaso $1 \%$ del total de sus resoluciones. No parece que la ejecución de las sentencias y autos del TC sea un asunto problemático en el derecho procesal constitucional español. No por ello deja de ser una cuestión interesante dogmáticamente.

4 La cita de los artículos 80, 87, 92 y 95.4 LOTC siempre se hace con referencia a su contenido reformado por la LORLOTC, salvo cuando se indique expresamente lo contrario. 


\section{LA REFORMA DE LA LOTC POR LA LEY ORGÁNICA 15/2015, DE 16 DE OCTUBRE, PARA LA EJECUCIÓN DE LAS RESOLUCIONES DEL TRIBUNAL CONSTITUCIONAL COMO GARANTÍA DEL ESTADO DE DERECHO. UN BREVE COMENTARIO}

La LORLOTC modifica los artículos 80, 87, 92 y 95 de la LOTC y su Disposición final única establece su entrada en vigor «el mismo día de su publicación en el» BOE (lo que tuvo lugar en el BOE n..$^{\circ}$ 249, de 17 de octubre de 2015).

En el artículo 80 LOTC, la LORLOTC introduce una remisión a la Ley de la Jurisdicción Contencioso-administrativa, en la actualidad la Ley 29/1998, de 13 de julio, reguladora de la Jurisdicción Contencioso-administrativa (en adelante, LJCA) como norma supletoria en «materia de ejecución de resoluciones», desplazando en este extremo a la Ley de Enjuiciamiento Civil (en adelante, LEC). Una modificación bienvenida por dos razones. De una parte, la redacción original del artículo 80 LOTC dejaba en penumbra la normativa aplicable a la ejecución de las resoluciones del TC, ya que ésta no era una de las materias enumeradas en el precepto y sujetas supletoriamente a lo dispuesto en la Ley Orgánica 6/1985, de 1 de julio, del Poder Judicial (en adelante, LOPJ) y en la LEC. No obstante, es cierto que el TC ha aplicado analógicamente otras leyes procesales, especialmente la LJCA, para materias no previstas expresamente en el artículo 80 y que tampoco hallaban regulación precisa en la LOTC 5 . Pero no lo ha hecho en materia de ejecución de sus resoluciones, donde siempre ha aplicado el artículo 92 LOTC, cuya escueta redacción original convertía al TC, parafraseando al BVerfG, en el «dueño de la ejecución» ${ }^{6}$, lo que conllevaba una indefinición sobre el modo y la

5 Sobre esta cuestión véase Huelin Martínez de Velasco, J., «Comentario al artículo 80», cit., pp. 1274 y 1275 .

6 Así se expresaba el alto tribunal alemán en su BVerfGE 6, 300 (303ff.), de 21 de marzo de 1957, en relación con el § 35 BVerfGG: «Aus dem umfassender Gehalt der Vorschrift, die das Gericht recht eigentlich zum Herrn der Vollstreckung macht, folgt aber, dass jene Anordnungen, wenn sich ihre Notwendigkeit erst nachträglich herausstellt, auch in einem selbständigen Beschluss des Gerichts getroffen werden können» ( «Del amplio contenido del precepto, que ciertamente hace del Tribunal el dueño de la ejecución, sin embargo resulta que esas disposiciones pueden adoptarse mediante resoluciones independientes del Tribunal, si ulteriormente se advierte su necesidad», traducción del autor). Sobre el alcance y polémica doctrinal sobre esa expresión véase BETHGE, ob. cit., pp. 9 y ss.; ROTH, W., «Grundlage und Grenzen von Übergangsanordnungen des Bundesverfassungsgerichts zur Bewältigung möglicher Folgeprobleme seiner Entscheidungen», $A r$ chiv des öffentlichen Rechts, Bd. 124, 1999, pp. 470 y ss., pp. 487 y ss.; y SCHLAICH/KORIOTH, Das Bundesverfassungsgericht. Stellung, Verfahren, Entscheidungen, C.H. Beck, München, 2004 (6. ${ }^{a}$ edic.), pp. 330 y 331. En cierto modo el § 35 BVerfGG, cuya literalidad está bien presente en la del artículo 92 LOTC, tanto en su redacción original como en la reformada, es un trasunto de los inespecíficos e implícitos poderes de la Supreme Court de los EEUU para hacer valer sus decisiones. Sobre esta cuestión y en términos generales véase BAUM, L., The Supreme Court, C.Q. Press, Los Angeles/London, 2015 (12. ${ }^{a}$ ed.), pp. 183 y ss. Esta ausencia de reglas precisas sobre la ejecución de las resoluciones de la Corte Suprema en ocasiones ha llevado a graves tensiones entre ésta y la jurisdicción ordinaria en el cumplimiento de las sentencias de la primera; quizá el caso más famoso sea el Florida ex rel. Hawkings v. Board of Control, 347 U.S. 971 (1954), 350 U.S. 413 (1956), 355 
manera de llevar a debido cumplimiento las resoluciones del TC, que parece haber querido precisar la actual reforma del precepto.

De otra, parece que el proceso ejecutivo del contencioso-administrativo, tanto por la similitud de su objeto (normas y actos del Poder público sometidos al control judicial) como por sus sujetos (Poderes públicos y los terceros afectados por las disposiciones, actos y vías de hecho de aquéllos), constituye probablemente la sede procesal más adecuada para articular procedimentalmente los incidentes de ejecución relativos a una resolución del TC. Claro está, y conviene señalarlo, que esto no altera ni puede alterar la competencia del orden jurisdiccional ordinario al que le corresponda ejecutar efectivamente la decisión del TC, y que lo hará sometido a sus normas procesales específicas (civiles, laborales o penales). Es el TC quien someterá sus incidentes de ejecución a lo dispuesto en la LJCA, no el órgano jurisdiccional al que el TC señale como sujeto responsable de la ejecución.

La reforma bien podría haber concluido aquí. Sin embargo también se reforma el artículo 87 introduciendo la potestad de notificación «personal» de las resoluciones del TC y la condición de título ejecutivo de sus resoluciones. Respecto de lo primero, conviene señalar que esa potestad es procesalmente superflua. Las resoluciones del TC se publican en el BOE y además se notifican a las partes en el proceso. Añádase que el artículo 80 remite a la LOPJ y a la LEC en los relativo a las comunicaciones y actos de auxilio judicial, y el artículo $149,4 .^{\circ}, 5 .^{\circ}$ y $6 .^{\circ} \mathrm{LEC}$, en lo que ahora importa, prevé como actos procesales de comunicación los requerimientos, mandamientos y oficios a través de los cuales el TC puede ordenar una actuación, inactividad o cualquier comportamiento necesario para dar por ejecutada una de sus resoluciones ${ }^{7}$. Por tanto, hay que entender que aquellas notificaciones personales adoptarán la forma según el caso de requerimientos, mandamientos u oficios. Parece, pues, que esa previsión de la notificación personal del reformado artículo 87 sirve al agravamiento de la responsabilidad en la que pueda incurrir la autoridad o empleado público que haga caso omiso de la notificación y de lo en ella notificado. En este extremo, lo aquí dispuesto habrá de conciliarse con lo establecido en el apartado 4 del artículo 92 LOTC, que apodera al TC para, advertido un incumplimiento de sus resoluciones, requerir «a las instituciones, autoridades, empleados públicos o particulares» a quiénes les cumplía ejecutar la resolución en cuestión para que informen al respecto. Cabría decir que la primera del artículo 87 es la norma general por la cual permite al TC no sólo identificar en sus resoluciones al responsable de su cumplimiento (artículo 92.1

U.S. 839 (1957), en el que la SCtUS llegó a pronunciarse en tres ocasiones en relación con la frustrada y finalmente no admitida solicitud de admisión de un ciudadano negro para ingresar en una Facultad de Derecho reservada para blancos, a pesar de que la SCtUS en aplicación de la Brownn v. Board of Education ordenó la tramitación de dicha solicitud. El Tribunal Supremo de Florida no ejecutó lo acordado por la SCtUS apelando a los límites que incluso la jurisdicción de la Corte tenía respecto de los ostentados por los tribunales estatales. El Sr. Hawkings no llegó a ingresar nunca en esa Facultad de Derecho.

7 Por todos, Huelín, ob. cit. pp. 1281 y ss. 
LOTC), sino además notificárselo personalmente (imposibilitando el alegato de desconocimiento o ignorancia); y la segunda, el requerimiento del artículo 92.4, lo es, no a los efectos de comunicar fehacientemente al responsable de la ejecución de lo resuelto su deber de llevarlo a su debido cumplimiento, sino para que informe de por qué no lo ha hecho.

El artículo 87.2 in fine LOTC establece la condición de título ejecutivo de las resoluciones del TC. Cuestión nada baladí, al incorporar las resoluciones del TC por medio del apartado 9 del artículo 517 LEC al limitado elenco de títulos ejecutivos de este precepto, que posibilitan de manera inmediata la acción ejecutiva forzosa sin mediar nuevo procedimiento. No cabe duda de que esta condición será sumamente útil para el caso de los recursos de amparo estimatorios; aunque la expresión «a estos efectos» parece constreñir la condición de título ejecutivo únicamente al caso de que el TC acuda al auxilio judicial, regulado en el Capítulo VI LEC. Extremo que parece poco lógico, ya que la función del título ejecutivo posee una conexión remota con el auxilio judicial. La primera permitiría a las partes en el proceso constitucional obtener de la jurisdicción ordinaria las resoluciones de ejecución forzosa que precisasen para hacer efectivo el cumplimiento de la resolución del TC que les resultase favorable (p.e., la puesta en libertad si no procediese de oficio la administración penitenciaria en el caso de la estimación de un amparo del artículo 17.1 CE, o la incorporación a un empleo público si así resultase de un amparo del artículo 23.1 CE). El segundo es un instrumento que llegado el caso podría resultarle útil al TC para la hipotética práctica de alguna diligencia procesal en el marco de un proceso constitucional, o la materialización de alguna de las medidas conminativas previstas en el apartado 4 del artículo 92 LOTC. No se olvide que la previsión relativa al auxilio judicial ya estaba en la redacción originaria del artículo 87 LOTC, por lo que parece razonable concluir que la expresión «a estos efectos» no pueda más que querer decir que las resoluciones del TC a fin de hacer efectivo su obligado cumplimiento por todos los poderes públicos tendrán las condición de títulos ejecutivos de inmediata observancia. El TC podría requerir el auxilio judicial del juez del lugar de residencia de la autoridad o empleado público que estuviese incurso en un caso del artículo 92.4 LOTC para que de forma preferente y urgente, con base en el título ejecutivo que constituye el Auto dictado tras el procedimiento previsto en el citado apartado 4 del artículo 92, haga efectiva la medida acordada en él (la multa coercitiva, la suspensión en sus funciones o la ejecución sustitutoria así dispuesta).

El artículo 92 resulta reformado en su integridad y constituye la más clara expresión de la condición del TC como «dueño de la ejecución de sus resoluciones» ${ }^{8}$. Impone primeramente al TC el deber de «velar» por el «cumplimiento 
efectivo de sus resoluciones». Este novedoso mandato carga sobre el TC la obligación de estar atento a que sus resoluciones se cumplan, y que además se cumplan efectivamente. Este deber suscita un buen número de interrogantes. Por una parte, no deja de resultar extremadamente dificultoso precisar el alcance de este deber e identificar la forma en la que puede controlarse su cumplimiento. Podría inferirse de ello que sería posible acudir al Tribunal Europeo de Derechos Humanos o al Tribunal de Justicia de la Unión Europea en el caso de que se consideren lesionados los derechos de los interesados a la ejecución en sus propios términos de las resoluciones judiciales (artículo 6 del Convenio Europeo y artículo 47 de la Carta Europea de Derechos Fundamentales), si el TC no hubiese actuado de oficio velando por el debido cumplimiento de las suyas.

No obstante, cabría pensar, con el fin de hacer razonable la norma, que al TC en realidad no se le hace ser destinatario de un deber, sino que se le apodera para poder actuar de oficio en el caso de que sus resoluciones no se lleven a debido efecto. Alguna duda existía sobre este particular con la redacción original del artículo 92 LOTC $^{9}$. Ahora, con la dada al apartado primero de este artículo puede sostenerse razonablemente que la LOTC habilita al TC para iniciar de oficio el incidente de ejecución de sus propias resoluciones (acaso incluso contra el criterio de las partes y el Ministerio Fiscal), excluyendo la aplicación supletoria del artículo 103.5 LJCA, que impide la actuación de oficio al legitimar sólo a las partes para instar el incidente de ejecución. La literalidad del apartado tercero del nuevo artículo 92 LOTC al referirse expresamente a la legitimación de las partes en el proceso para instar el incidente, avala esta conclusión. No hubiera estado de más que el legislador hubiese puesto más esmero y claridad técnicas en la redacción del precepto.

Añade el nuevo artículo 92.1 LOTC que el TC podrá disponer en la resolución correspondiente «las medidas de ejecución necesarias» y «declarar la nulidad de cualesquiera resoluciones que contravengan las dictadas en el ejercicio de su jurisdicción, con ocasión de la ejecución de éstas, previa audiencia del Ministerio Fiscal y del órgano que las dictó». Expresiones y habilitaciones que se habían introducido en el artículo 4 LOTC tras su reforma por la Ley Orgánica 6/2007, de 24 de mayo, y que aún permanecen. En ambos casos se regula un incidente de ejecución cuyo objeto son las resoluciones o actos (hay que entender que así es por analogía de lo dispuesto en el artículo 4 LOTC, pues el artículo 92.1 no habla de «actos», lo que es una omisión inexplicable) que incumplan, menoscaben o contravengan material o jurídicamente las resoluciones dictadas en el ejercicio de su jurisdicción, como reiteradamente ha dicho el TC, y que se articula en un breve procedimiento en el que es oído el Ministerio Fiscal y el órgano que dictó la resolución.

la nueva redacción dada al citado artículo 4 el siguiente texto: «Podrá también declarar la nulidad de cualesquiera resoluciones que contravengan las dictadas en el ejercicio de su jurisdicción, con ocasión de la ejecución de éstas, previa audiencia del Ministerio Fiscal y del órgano que las dictó».

9 Huelin, ob. cit., p. 1377. 
El artículo 92 prosigue con nuevos apartados 2 a 5 donde regula un remedo de auxilio y cooperación «administrativas» que se suma a la judicial prevista en el artículo 87.2 LOTC, lo hace también de la posibilidad expresa de que el incidente de ejecución se inicie a instancia de parte, y el meollo cierto de esta reforma, la regulación de un incidente de ejecución dirigido a conminar a las instituciones, autoridades, empleados públicos o particulares sujetos al cumplimiento de sus resoluciones en caso de que no lo hagan por sí mismos ${ }^{10}$. Si el TC considera que no se ha cumplido en parte o en todo su resolución, podrá imponer a los obligados a cumplir una multa coercitiva, suspenderles temporalmente en sus funciones, la ejecución sustitutoria con la colaboración del Gobierno de la Nación o exigir responsabilidades penales ${ }^{11}$. El apartado 5 prevé un incidente específico para el caso de que lo incumplido sean sus resoluciones de suspensión de disposiciones, actos o actuaciones, en el que el TC de oficio o a instancia del Gobierno de la Nación y sin oír a las partes puede adoptar las medidas que considere pertinentes para asegurar la suspensión acordada. En esta misma resolución, que hay que entender que debería adoptar la forma de auto, emplazará, ahora sí, al Ministerio Fiscal y a las partes para que aleguen lo que convenga. Una vez oídas o transcurrido el plazo para hacerlo el TC dictará nueva resolución ratificando, modificando o levantando las medidas acordadas provisionalmente.

Llama la atención en estos dos apartados la posición privilegiada que ocupa el Gobierno de la Nación en ambos casos, y los problemas de interpretación sistemática que ofrece ese apartado 5. En primer lugar, sólo el Gobierno de la Nación puede ser requerido para colaborar con el TC en la aplicación de la ejecución sustitutoria de la letra d) del artículo 92.4. La literalidad del precepto parece pensar no tanto en que se pueda acordar una ejecución materialmente distinta a la que resulte inicialmente de lo resuelto por el TC, sino en la sustitución de la institución, autoridad, empleado público o particular responsable originalmente de cumplir con ello por otro, para lo que podrá requerir la colaboración del Gobierno de la Nación. Si a ello sumamos que sólo el Gobierno de la Nación puede instar el incidente de ejecución urgente del apartado 5, resulta que la reforma atribuye al Gobierno de la Nación un posición que olvida la existencia de las Comunidades Autónomas, y la condición de España de Estado descentralizado, lo que arroja alguna sombra sobre la constitucionalidad de este precepto (algo diremos de esto más abajo). En se-

10 En efecto, a nuestro juicio, el TC no debería dar inicio al incidente de ejecución si la parte que lo promueve no le ha dado antes a la institución, autoridad o empleado público renuentes la posibilidad de ejecutar la resolución del TC, debiendo pues agotar la vía judicial ordinaria pertinente antes de acudir al TC, máxime si las resoluciones del TC son un título ejecutivo.

11 Aquí la panoplia de posibilidades es grande según el caso, así podría deducirse testimonio por la comisión de alguno de los Delitos contra la Administración Pública (prevaricación, desobediencia y denegación de auxilio) y contra la Constitución (rebelión). 
gundo lugar, de esta literalidad podría inferirse que el Gobierno de la Nación está excluido de ambos incidentes, tanto del regulado en el apartado 4, cuanto del previsto en el apartado 5 . Incluso podría interpretarse que la posición procesal del Gobierno en este apartado 5 se ampara en el privilegio previsto en el artículo 161.2 CE en relación con la suspensión temporal y automática de disposiciones y actos de las Comunidades Autónomas. Este apartado 5 y la propia colaboración del Gobierno en la ejecución sustitutoria de la letra d) del apartado 4, parecen erigirse en instrumentos procesales al servicio de la lealtad constitucional, complementando el artículo $155 \mathrm{CE}$. Sin embargo, la recta interpretación del artículo 92.4 y 5 LOTC no permite en rigor esa exclusión, y tampoco parece justificada esa conexión con los instrumentos de la lealtad constitucional, en la medida en que el Gobierno de la Nación y su Administración no están exentos del cumplimiento de lo resuelto por el TC, y por tanto, de ser sujetos pasivos en el correspondiente incidente de ejecución, o en su caso de los incidentes conminatorios de los apartado 4 y 5 del artículo $92 \mathrm{LOTC}^{12}$.

En efecto, quizá la interpretación constitucionalmente más conforme de estos apartados pueda ser que el TC podrá acudir al Gobierno de la Nación para imponer ejecuciones sustitutorias que no le afecten a él como órgano constitucional, pues si le afecta, el TC podrá adoptarlas por sí mismo en los términos del artículo 92.1 LOTC. En el caso de las suspensiones, considerar que el incidente de ejecución del artículo 92.1 LOTC también es de aplicación en el caso de que lo incumplido sean resoluciones suspensivas del TC (como viene haciendo el TC regularmente en aplicación del artículo 92 original), quedando reservado el incidente urgente y provisional del apartado 5 para aquellos casos en los que «concurran circunstancias de especial trascendencia constitucional» que requieran esa actuación inaudita parte del TC (sólo justificable por concurrir aquellas circunstancias especiales), en los que el TC actúa de oficio (sin perjuicio de que su celo resulte excitado por la petición de terceros), pudiendo hacerlo a instancia del Gobierno de la Nación únicamente si la suspensión controvertida se hubiese acordado al amparo del artículo 161.2 CE.

La reforma se cierra con un nuevo apartado 4 del artículo 95 que establece una reserva a la ley ordinaria de la modificación de las cuantías de las multas coercitivas. No deja de resultar llamativa está técnica, en la que, por lo demás, este nuevo apartado 4 cumpliría la función de disposición adicional que identifica las materias conexas y no sujetas a la reserva del artículo $81 \mathrm{CE}^{13}$.

12 Sobre la lealtad constitucional véase Álvarez Álvarez, L., La Lealtad constitucional en la Constitución española de 1978, CEPC, Madrid, 2008.

13 Es ésta una cuestión técnicamente llamativa de esta Ley Orgánica. Fijar las cuantías de una multa coercitiva acaso no fuese materia de ley orgánica. Quizá también piensa el legislador orgánico que en este preciso supuesto no cabe acudir a la técnica de las materias conexas y declarar en la oportuna adicional que el apartado 4 del artículo 90 no es orgánico en relación con las cuantías. Pero el caso es que la reserva de ley 
No resulta de mucha ayuda el debate parlamentario en torno a la tramitación y aprobación en lectura única de la Proposición de Ley promovido por el Grupo Parlamentario Popular al filo de la conclusión de la XI Legislatura ${ }^{14}$, más allá del sostenido entre los portavoces del Grupo proponente y del Grupo Socialista, que insistía en lo innecesario de esta reforma y de sus dificultades y tachas técnicas, incluso su contrariedad con la CE. Lo que sí deja evidente el debate parlamentario es que la última razón de la urgencia de esta reforma no es otra que la deriva independentista de las instituciones autonómicas catalanas, en particular su Parlament y su Generalitat, redoblada tras las últimas elecciones autonómicas en Cataluña. Los promotores deseaban poner a disposición del TC poderes de ejecución de sus resoluciones que asegurasen su cumplimiento estricto (como si antes de esta reforma, esto no pudiese ser asî $)^{15}$.

La LORLOTC ha sido recurrida por el Gobierno de Cataluña ${ }^{16}$ y por el Gobierno $\mathrm{Vasco}^{17}$. Ambos impugnan el artículo 92.4 letras a), b) y c), y el apartado 5. También fue objeto de una Proposición de Ley de derogación de la LORLOTC (Presentado el 19/04/2016, y en la actualidad caducada al concluir la Legislatura XI), presentada por el Grupo Parlamentario Catalán.

Esta última considera que esta LORLOTC es una «reforma encubierta» de la CE, cuyo artículo 164 nada diría sobre hipotéticas potestades de ejecución del TC. Además, esta reforma alteraría sustancialmente la naturaleza del TC que dejaría de ser un «árbitro» entre los Poderes del Estado o sus territorios para convertirse en un «tribunal ordinario, obligado a hacer cumplir directamente sus resoluciones e incluso a ejecutarlas». Una obligación que a los ojos de los proponentes concentra un excesivo poder en un TC aquejado de una legitimidad demo-

orgánica en este caso se refiere a la regulación del TC y tenemos alguna duda sobre si en efecto cabe excluir de la reserva la fijación de esas cuantías. Incluso la necesidad de que sean objeto de revisión.

14 Proposición de LO de reforma de la LOTC, para la ejecución de las resoluciones del Tribunal Constitucional como garantía del Estado de Derecho (122/000213), que fue presentado el 01/09/2015.

15 Bien es sabido que este conflicto «catalán» se inicia con la STC 31/2010 por la que se declara parcialmente inconstitucional el Estatuto de Cataluña de 2007, a la que siguieron las Sentencia relativas a la declaración del Parlament sobre el inicio del proceso de independencia de Cataluña (STC 42/2014), las sentencias sobre la ley catalana de consultas no refrendarias y el Decreto de convocatoria de la consulta del 9 de noviembre de 2014 (SSTC 31 y 32/2015) y la que anuló la declaración de desconexión del Estado español (STC 259/2015) y la más reciente que declara contrarias a la CE una serie de leyes cuyo objeto es la creación de diversas instituciones catalanas (STC de 7 de julio de 2016).

16 Recurso de inconstitucionalidad n. $.^{0} 7466 / 2015$, promovido por contra la LO15/2015, de 16 de octubre, de reforma de la LO 2/1979, de 3 de octubre, del Tribunal Constitucional, para la ejecución de las resoluciones del Tribunal Constitucional como garantía del Estado de Derecho, así como contra su artículo único. Tres, por la redacción dada a los artículos 92.4.a), .b) y último inciso del .c), y .5 de la LO 2/1979, de 3 de octubre. Presentado el 05/02/2016, calificado el 09/02/2016.

17 Recurso de inconstitucionalidad n. ${ }^{\circ}$ 229/2016, promovido por el Gobierno Vasco, contra la LO 15/2015, de 16 de octubre, de reforma de la LO 2/1979, de 3 de octubre, para la ejecución de las resoluciones del Tribunal Constitucional como garantía del Estado de Derecho, así como contra el artículo único apartado tres de la misma en la redacción dada a las letras b) y c) del apartado 4 y al apartado 5 del artículo 92 de la LOTC. Presentado el 05/02/2016, calificado el 09/02/2016. 
crática «indirecta» y que no puede sustituir los restantes poderes constitucionales en la ejecución de sus resoluciones sin menoscabar gravemente el principio de división de poderes ${ }^{18}$.

A renglón seguido la Proposición incide en otro aspecto ciertamente problemático de esta Ley, pues «La reforma llega a otorgar al Tribunal Constitucional la potestad de suspender de sus funciones y durante el tiempo que haga falta, a cargos elegidos democráticamente por los ciudadanos, lo cual incluso puede alcanzar al Presidente del Gobierno. Sin embargo la Constitución solo contempla el cese del Presidente del Gobierno tras la celebración de elecciones generales, por pérdida de confianza parlamentaria o por dimisión o fallecimiento del Presidente. En otras palabras, con la mencionada Ley, se ceden al Tribunal Constitucional, unas potestades de una carga política impresionante, como es el caso de suspender de funciones al President de la Generalitat o al Presidente del Gobierno, autoridades elegidas democráticamente, lo cual resulta inadmisible, más aún cuando la politización de la institución Tribunal Constitucional es tan notable».

La Proposición, no cabe duda, apunta a alguna debilidad de esta reforma. No tanto por la rebaja del TC a la condición de tribunal «ordinario» que debe cuidar de la ejecución de sus sentencias, lo que en realidad no es ningún inconveniente constitucional por las razones que más abajo desgranaremos siquiera sucintamente. Tampoco porque resulte insólito en el panorama constitucional comparado que la jurisdicción constitucional esté dotado del poder de ejecutar sus resoluciones. Pero sí son debilidades de esta reforma la extensión que se le ha querido dar al poder de ejecución del TC, especialmente esa potestad de apartar a los cargos públicos temporalmente de sus funciones (y que no hay motivo expreso para excluir de ese caso al Jefe del Estado, al Presidente del Gobierno o al de las Cortes Generales), lo que afecta a su posición sistémica en la arquitectura constitucional española. Un extremo que reproduce en España el debate de la doctrina alemana en torno al BVerfG en la condición de «dueño de la ejecución» de sus resoluciones.

La reforma hubiese quedado confinada en lo deseable, si se hubiese limitado a precisar ciertos detalles necesitados de concreción relativos a la forma de hacer cumplir las resoluciones del TC (como la supletoriedad de la LJCA o la condición de títulos ejecutivos de sus resoluciones). Pero el legislador circunstancial ha

18 Así lo expresa la Proposición de Ley: «Esta obligación difícilmente se podrá hacer sin vulnerar el principio de separación de poderes y sin alterar el sistema de contrapesos institucionales definidos por la Constitución, ya que es evidente que el Tribunal Constitucional no puede llegar a sustituir al legislador, al Gobierno del Estado, el poder judicial o los poderes territoriales, en la ejecución de sus decisiones. ... Además, cabe recordar que la falta de potestades ejecutivas de los Tribunales Constitucionales, como la previsión de que sólo pueden actuar a instancia de las partes legitimadas por la Constitución cuando plantean sus demandas, resulta precisamente de la necesidad de limitar el poder de un órgano que ya está dotado de las máximas potestades, como es la de anular las leyes aprobadas por los representantes electos del pueblo. Si, además, se atribuyen a este Tribunal las potestades para ejecutar directamente sus Sentencias, posiblemente se está concentrando en un órgano, que sólo tiene una legitimación democrática indirecta, un exceso de poder cuyo ejercicio no podrá ser objeto de control por ninguna otra institución del Estado». 
querido ir más allá, urgido por una situación política excepcional (el proceso independentista catalán), y, todo hay que decirlo, por una larvada desconfianza en la firmeza y resolución del TC en hacer ejecutar lo que ha juzgado.

\section{EL PRIMER CASO DE APLICACIÓN: AUTO DEL TRIBUNAL CONSTITUCIONAL 141/2016, DE 19 DE JULIO, Y ACTUACIONES SUBSIGUIENTES}

El TC ha tenido oportunidad de aplicar el nuevo incidente de ejecución diseñado por la LORLOTC en su Auto de Pleno 141/2016 con ocasión del promovido por el Gobierno de la Nación en cumplimiento de lo resuelto en la STC 259/2015, de 2 de diciembre, contra la Resolución 5/XI del Parlamento de Cataluña de 20 de enero de 2016 de creación de comisiones parlamentarias en la que se crea la Comisión de Estudio del Proceso Constituyente.

La citada STC 259/2015 declaró inconstitucional y nula la Resolución del Parlamento de Cataluña 1/XI, de 9 de noviembre de 2015, y su Anexo, sobre el inicio del proceso político en Cataluña como consecuencia de los resultados electorales del 27 de septiembre de 2015. En esta Sentencia, y en lo que ahora importa, el TC considera que el Parlamento de Cataluña manifestó en dicha resolución su voluntad de iniciar un proceso constituyente en Cataluña al margen de los procesos de reforma constitucional previstos en la CE para la creación de la República de Cataluña. La cámara parlamentaria autonómica se proclamaba en ella depositaria de la soberanía del Pueblo catalán y expresión de su poder constituyente, instando al gobierno catalán a que únicamente cumpla con sus mandatos. El TC recuerda en su Sentencia que conforme a los artículos 1.2 y 2 CE, no hay más soberano que el Pueblo español, que lo es de forma indivisible y única, razón por la que sólo hay un Estado, el español, cuya unidad e indivisibilidad se funda en la del Pueblo español en su condición de único soberano. Es el Pueblo español el que ha constituido el Estado española en ejercicio de su poder constituyente, por lo que ningún otro poder constituido puede atribuirse el ejercicio de la soberanía ni la condición de poder constituyente de un pueblo, el catalán en este caso, que no posee esa condición, ni puede poseerla en la CE sin infringir los citados preceptos constitucionales y los relativos a la reforma constitucional.

Y el TC añade como corolario de todo lo dicho (FJ 4): «Como consecuencia recae sobre los titulares de cargos públicos un cualificado deber de acatamiento a dicha norma fundamental, que no se cifra en una necesaria adhesión ideológica a su total contenido, pero sí en el compromiso de realizar sus funciones de acuerdo con ella y en el respeto al resto del ordenamiento jurídico (en tal sentido, entre otras, SSTC 101/1983, de 18 de noviembre, FJ 3, y 122/1983, de 16 de diciembre, FJ 5). Que esto sea así para todo poder público deriva, inexcusablemente, de la condición de nuestro Estado como constitucional y de Derecho. «El sometimiento de todos a la Constitución es «otra forma de sumisión a la voluntad po- 
pular, expresada esta vez como poder constituyente» [SSTC 108/1986, de 29 de julio, FJ 18, y 238/2012, de 13 de diciembre, FJ 6 b)]. En el Estado constitucional, el principio democrático no puede desvincularse de la primacía incondicional de la Constitución, que, como afirmó este Tribunal en la STC 42/2014, FJ 4 c), «requiere que toda decisión del poder quede, sin excepción, sujeta a la Constitución, sin que existan, para el poder público, espacios libres de la Constitución o ámbitos de inmunidad frente a ella». «Para garantizar que esto último no ocurra se cuenta con el sistema de nuestro Estado constitucional de Derecho - los poderes públicos, pero también la ciudadanía- y, en última instancia, cuando así se le requiera, con este Tribunal Constitucional. A él corresponde «en su función de intérprete supremo de la Constitución (art. 1 LOTC), custodiar la permanente distinción entre la objetivación del poder constituyente y la actuación de los poderes constituidos, los cuales nunca podrán rebasar los límites y las competencias establecidas por aquél» (STC 76/1983, de 5 de agosto, FJ 4)»

El TC concluye que la Resolución impugnada es la expresión de una manifiesta voluntad de no sujeción a la CE y al ordenamiento jurídico en ella fundado y por ella constituido, y le corresponde al TC velar por la incondicionada sujeción de todos los Poderes Públicos a la CE, norma suprema. Finalmente el TC declara inconstitucional la Resolución por ser expresión del rechazo a la fuerza de obligar de la CE misma infringiendo los artículos 1.1 y 2, 2 y 9.1 CE, y también el artículo $168 \mathrm{CE}$ porque el Parlamento catalán se ha apartado voluntaria y decididamente con dicha Resolución del cauce previsto por la propia CE para reformar llegado el caso el orden constitucional existente, tal y como se propone en ella en relación a Cataluña. Dice su FJ 7: «La Cámara autonómica no puede erigirse en fuente de legitimidad jurídica y política, hasta arrogarse la potestad de vulnerar el orden constitucional que sustenta su propia autoridad. Obrando de ese modo, el Parlamento de Cataluña socavaría su propio fundamento constitucional y estatutario (arts. 1 y 2.4 EAC, antes citados), al sustraerse de toda vinculación a la Constitución y al resto del ordenamiento jurídico, e infringiría las bases del Estado de Derecho y la norma que declara la sujeción de todos a la Constitución (arts. 1.1 y 9.1 CE). Este Tribunal dijo ya en la STC 103/2008 que el respeto a los procedimientos de reforma constitucional es inexcusable, de modo que «tratar de sortear, eludir o simplemente prescindir de esos procedimientos sería intentar una inaceptable vía de hecho (incompatible con el Estado social y democrático de Derecho que se proclama en el art. 1.1 CE) para reformar la Constitución al margen de ella o conseguir su ineficacia práctica» (FJ 4). Esto es lo recogido en realidad en la resolución 1/XI, cuya apariencia de juridicidad — por provenir de un poder sin duda legítimo en origen- debe ser cancelada mediante la declaración de inconstitucionalidad que aquí se decide.

«Como afirmamos en la STC 42/2014 (FJ 4), el planteamiento de concepciones que pretendan modificar el fundamento mismo del orden constitucional tiene cabida en nuestro ordenamiento, siempre que no se prepare o defienda a través de una activi- 
dad que vulnere los principios democráticos, los derechos fundamentales o el resto de los mandatos constitucionales, y el intento de su consecución efectiva se realice en el marco de los procedimientos de reforma de la Constitución. Cuando, por el contrario, se pretenden alterar aquellos contenidos de manera unilateral y se ignoran de forma deliberada los procedimientos expresamente previstos a tal fin en la Constitución, se abandona la única senda que permite llegar a ese punto, la del Derecho».

El resultado de estas últimas expresiones del TC es que cualquier actuación del Parlamento catalán, o de los Poderes públicos catalanes, que reiteren o insistan en la vía de hecho abierta por la Resolución 1/XI de 9 de noviembre de 2015 y se aparten del cauce reglado de la reforma constitucional conforme lo dispuesto en el Título X CE para la creación de la República de Cataluña, es inconstitucional y nula. La Resolución 5/XI del Parlamento de Cataluña, objeto del Auto que nos ocupa, se trata indudablemente de un acto jurídico que al crear una Comisión parlamentaria de Estudio del Proceso Constituyente para la creación de la República de Cataluña ${ }^{19}$ insiste en un camino que el TC vedó en su STC 259/2015 y que, además, consideró contrario a la CE y nulo. El asunto aquí es dilucidar si la vía procesal adecuada para hacer valer esa inconstitucionalidad de la mentada Resolución debiera ser una vez más el procedimiento del Título V LOTC (impugnación de las resoluciones de las Comunidades Autónomas por el Gobierno de la Nación por motivos no competenciales), o habría que acudir al incidente de ejecución de la STC 259/2015 regulado en el artículo 92 LOTC. Todo depende de si la Resolución es tomada por un acto de desobediencia de la STC 259/2015; o si se trata de un nuevo acto autónomo y de contenido específico del Parlamento catalán contrario a la Constitución y nulo por insistir en una vía política que el TC ha declarado inconstitucional, y que así debe ser declarado de nuevo por el TC en aplicación de su propia jurisprudencia una vez sustanciado el oportuno procedimiento del Título V LOTC. Lo cierto es que ni las partes ni el propio TC en el Auto en cuestión se han planteado este óbice procesal, según se desprende de los Antecedentes de la resolución del Alto Tribunal, cuando hubiese convenido para despejar esa incógnita y establecer los criterios que permitan discernir en casos futuros que vía procesal seguir.

A nuestro juicio, no es difícil colegir que la Resolución 5/XI por la que se crea la Comisión de Estudio del Proceso Constituyente es un acto ejecutado en cumplimiento de lo acordado en la Resolución 1/XI (apartados II y III), declarada inconstitucional y nula en la STC 259/2015. Por tanto constituye un acto manifiesto de desobediencia a lo resuelto en la STC 259/2015. Lógico entones que se acuda, como ha hecho el Gobierno de la Nación, al incidente de ejecución con la pretensión de que se cumpla la STC 259/2015 y se declare nula, no pro-

19 Vamos a dejar para otra ocasión el interesantísimo debate sobre la cuestión relativa a la calidad jurídica de esa Resolución y de si en efecto tiene o no efectos jurídicos, como el TC ha considerado, pues no es éste el lugar para ello, ni el propósito de este artículo. 
piamente por inconstitucional (que lo es y con los mismos fundamentos que lo fue aquella de la que trae causa), sino por ser un acto de desobediencia de la STC 259/2015. De ahí también que el debate procesal en el incidente acaso no debiera haber versado tanto sobre la inconstitucionalidad de la Resolución 5/XI (como así debiera ser si se hubiese impugnado por la vía del Título V LOTC), cuanto sobre si en efecto es un acto en ejecución y amparado en una Resolución previa declarada inconstitucional y nula (obviamente el motivo de impugnación en el incidente no es material, sino procesal y su parámetro de control es la propia resolución del TC cuyo cumplimiento se pretende). El acto de desobediencia no estriba en el incumplimiento del fallo de la STC 259/2015, que se limitó a anular por inconstitucional la Resolución 1/XI; sino en el incumplimiento de la doctrina del TC sobre hipotéticos procesos constituyentes autonómicos al margen de las reglas de reforma constitucional que el TC ha ido desgranando en una ya larga secuencia de resoluciones que se iniciaron con la STC 31/2010, continuó en la 42/2014 y encuentra su última expresión en la 259/2015.

El Abogado del Estado en representación del Gobierno de la Nación y del Ministerio Fiscal en el incidente de ejecución resuelto por el Auto 141/2016 plantean el asunto materialmente más como una impugnación del Título $\mathrm{V}$ LOTC (que no lo es formalmente, pue no fue el cauce elegido), que en rigor un incidente de ejecución por cuanto despliegan toda una batería de argumentos para demostrar que la Resolución 5/XI persigue la misma finalidad y se asienta en competencias y poderes del Parlamento catalán que el TC en su STC 259/2015 ya había declarado sin amparo en la CE. No debieran ser ésos los términos de la controversia, ni esa la pretensión del Gobierno de la Nación en un incidente de ejecución de la STC 259/2015, en nuestra opinión claro está. La creación y la constitución de la Comisión en cuestión es un acto de desobediencia de lo fallado en la STC 259/2015 en tanto ésta declaró inconstitucional y nula la Resolución de la que trae causa, siquiera remota, la que es objeto del incidente de ejecución. De no existir esa conexión, que no está en la comunión de fines sino en el hecho de que la segunda resolución es desarrollo de la primera en la que encuentra amparo (se crea una Comisión parlamentaria para estudiar e informar al Parlamento catalán sobre los pasos a seguir y las distintas posibilidades que se abren en el inicio del proceso de creación de la república catalana acordado en la Resolución 1/XI), el TC hubiera debido inadmitir el incidente de ejecución y remitir al Gobierno de la nación a una nueva impugnación del Título V. Nada hay en la LORLOTC que permita concluir que se ha alterado las condiciones procesales de los incidentes de ejecución ante el TC o que los haya convertido en un remedo de recurso especial contra actos y resoluciones singulares por infracción de la jurisprudencia del TC.

Un incidente de ejecución no es la vía procesal adecuada para discutir sobre la constitucionalidad de un acto o disposición, o sobre su conformidad con la jurisprudencia del TC. Lo es únicamente para examinar si ese acto o disposición son la expresión de una desobediencia a lo resuelto en un caso concreto por el TC, 
aun cuando ese acto o resolución no fuesen materialmente contrarios a la CE, como no lo es crear y constituir una Comisión parlamentaria de estudio. Esta idea late en el propio Auto cuando modula el alcance de su fallo porque no puede evitar reconocer que la mera creación y constitución de una Comisión parlamentaria de Estudio no es contrario a la CE, y que su tacha no es por contrariar la CE sino por ser un acto de desobediencia de una resolución del TC.

La representación procesal del Parlamento de Cataluña apunta en esa dirección: una iniciativa parlamentaria de resultado aún incierto no puede ser considerada «un supuesto de incumplimiento de una sentencia» (apela el Parlamento catalán, además, a la doctrina de los interna corporis acta y al ius ad officium de los parlamentarios), y esgrime también la falta del «necesario nexo jurídico» que debe mediar entre ambas Resoluciones de manera que la que es objeto de incidente de ejecución pueda considerarse «un desarrollo o aplicación de la primera». Para la representación procesal del Parlamento catalán este incidente resulta prematuro y solicita su inadmisión (y subsidiariamente su desestimación).

El TC delimita el alcance de su análisis al contraerlo a si el Parlamento de Cataluña con su Resolución 5/XI ha desconocido lo resuelto en la STC 259/2015 (FJ 2). En ese mismo FJ 2 el TC repasa su doctrina en materia de cumplimiento y ejecución de sus resoluciones, y subraya que la vinculación del artículo 87.1 LOTC alcanza tanto al fallo como a la fundamentación jurídica de sus resoluciones (lo que es doctrina reiterada del TC).

EL TC atina al detenerse en la necesaria concreción de cuál deba ser el objeto de este incidente, y tras sintetizar el alegato del Abogado del Estado, advierte que no es objeto del incidente «enjuiciar el contenido de la Resolución»... «sino resolver ... si ... contraviene de forma clara los mandatos derivados de la Sentencia» 259/2015 (FJ 4). Una vez más el TC acude a su razonable estándar de la evidencia de la lesión para evitar su activismo, y juzgará no sobre propósitos ni intenciones, sino sobre la literalidad de la Resolución objeto del incidente y sus efectos jurídicos.

En primer lugar el TC da respuesta al argumento vertido por el Parlamento catalán sobre el carácter «preventivo» del incidente dado que la Resolución 5/XI es un interna corporis acta que por sí no tiene capacidad para contravenir la STC 259/2015, ya que se limita a crear una comisión parlamentaria de estudio. Para el TC la Resolución 5/XI es un acto parlamentario con efecto jurídico que la hace susceptible de control constitucional y versa sobre «el llamado proceso constituyente en Cataluña», lo que permite ponerla de manera evidente en relación «con los fines de la Resolución I/XI» declarada inconstitucional y nula en la STC 259/2015 (FJ 4). En segundo lugar el TC hace un largo excursus por el contenido de la STC 259/2015 y al amparo de sus razonamientos sostiene, de un lado, que en sede parlamentario todo puede ser objeto de un libre debate en su especial condición de «escenario privilegiado del debate público» (STC 226/2004, FJ 6). Pero esta libertad no es excusa para «arrogarse la potestad de vulnerar el propio orden constitucional que sustenta su propia autoridad» (con cita una vez más de 
la STC 259/2015 FJ 7) pretendiendo ser sede de una soberanía distinta a la del Pueblo español del artículo 1 de la CE y promoviendo la revisión sustancial del sistema constitucional español al margen de los procedimiento de reforma constitucional que en el caso español carecen de límites materiales (como recuerda el ATC, todo puede ser debatido, pero transformar lo debatido en norma debe sujetarse a las que regulan la toma de decisiones en nuestro sistema constitucional democrático, so pena de vulnerar el Estado de Derecho); y de otro, el «deber de fidelidad a la Constitución» que pesa sobre los poderes públicos (STC 247/2007 FJ 4), debiendo velar porque sus decisiones se acomoden al orden constitucional vigente y al ordenamiento jurídico cuya validez trae causa de él, recayendo sobre los titulares de esos poderes públicos «un cualificado deber de acatamiento» a la $\mathrm{CE}$, lo que, como es bien sabido no comporta una «adhesión ideológica a su total contenido, pero sí en el compromiso de realizar sus funciones de acuerdo con ella y en el respeto al resto del ordenamiento jurídico» (con cita de las SSTC 101/1983 FJ 3, 122/1983 FJ 5 y 259/2015 FJ 4). Someterse a la CE y al ordenamiento que de ella nace, concluye el TC (FJ 5), no es más que la expresión de la sumisión de todos, poderes públicos y ciudadanos, a la voluntad del Pueblo español soberano (SSTC 108/1986 FJ 18, 238/2012 FJ 6 b, 259/2015 FJ 4).

Hasta aquí el ATC es irreprochable, pero el final pone de manifiesto la debilidad del argumentario del TC en el incidente. En efecto, todo lo expuesto conduce necesariamente a un análisis sobre la constitucionalidad de la Resolución 5/ $\mathrm{XI}$, fuertemente debilitado en su condición de acto de creación de una mera Comisión parlamentaria de estudio (y el TC lo intuye así dadas las palabras con las que abre su FJ 6 al referirse a la imposibilidad de considerar inconstitucionales las «meras propuestas sujetas a examen y discusión posterior» con cita del ATC 135/2004 sobre la constitucionlidad de una iniciativa en sede parlamentaria cuyo éxito sólo era posible si antes se reformaba la CE). Al TC le hubiera bastada para salvar este escollo no haber planteado la cuestión como un «intento de menoscabar» jurídica o materialmente el fallo y los fundamentos jurídicos de la STC 259/2015 al hacer caso omiso de su doctrina sobre la soberanía y el poder constituyente democráticos en la CE (un problema en definitiva de constitucionalidad material de la propia resolución, como lo fue de la que le precedió y declaro inconstitucional y nula la STC 259/2015), tal y como plantearon el Gobierno de la Nación y la Fiscalía. Le hubiera bastado con comprobar si la Resolución objeto del incidente por la que se creaba la comisión parlamentaria en cuestión podría considerarse un acto de aplicación, desarrollo o ejecución de la Resolución I/XI que el TC declaró nula por inconstitucional, de manera que si así fuese, aquélla primera sería un evidente incumplimiento de lo resuelto en la STC 259/2015 al aplicar y desarrollar una resolución que previamente fue declarada nula por inconstitucional. Este debió ser, a nuestro juicio, el razonamiento que sustentase lo acordado en el Auto.

Pero el TC da un giro a su argumentación y adopta una posición ciertamente ponderada y cauta, acaso en exceso, forzada por el propio decurso de sus argu- 
mentos. Respetuoso con la autonomía parlamentaria (y probablemente consciente de que no estaba falta de razón la representación procesal del Parlamento catalán al sostener al hilo de la propia jurisprudencia del TC que la Resolución atacada es un simple acto de trámite parlamentario aún sin contenido jurídico alguno, pues cabría la posibilidad de que el estudio de la Comisión concluyese justamente diciendo lo mismo que el propio TC en su Sentencia 259/2015 — que el único camino constitucionalmente lícito y, acaso, legítimo democráticamente para crear la república de Cataluña es a través de la previa reforma de la CE-), y apelando a circunstancias «especiales» del caso para justificar su admisión a trámite y la estimación del incidente, considera que, a pesar de la comunión de «fines» entre ambas Resoluciones, la inconstitucional y la impugnada en este trámite, y de que la segunda pueda ser «entendida como un intento de dar apariencia de validez al denominado proceso constituyente en Cataluña, cuya inconstitucionalidad fue declarada por la STC 259/2015» (FJ 6), el alcance de su resolución debe limitarse al caso hipotético de que la comisión dirija sus trabajos y conclusiones más allá del análisis de las posibles alternativas para reformar la CE con el objeto de allanar el camino para «satisfacer cualquier pretensión política» (FJ 7), pues:

«...no resulta constitucionalmente admisible es que la actividad parlamentaria de «análisis» o «estudio» se dirija a dar continuidad y soporte al objetivo proclamado en la Resolución 1/XI — la apertura de un proceso constituyente en Cataluña encaminado a la creación de la futura constitución catalana y del estado catalán independiente en forma de república-, que fue declarado inconstitucional por la STC 259/2015 en los términos ya expuestos. En suma, la actividad de la comisión creada resulta absolutamente inviable si no se entiende condicionada al cumplimiento de las exigencias de la Constitución y, singularmente, de los procedimientos para su reforma y, en general, a los marcos que rigen para la actividad política, los cuales han sido definidos por el Tribunal con continuidad y firmeza en las sentencias que hemos venido citando Así lo declara el Tribunal, advirtiendo asimismo a los poderes implicados y a sus titulares, bajo su responsabilidad, de su deber de impedir o paralizar cualquier iniciativa que suponga ignorar o eludir estos mandatos» (FJ 7).

$\mathrm{Y}$ a resultas de estas razones el TC dicta una Auto interpretativo de rechazo (si tal cosa puede existir), pues estima el incidente, pero en los términos del FJ 7. Esto es, la Resolución no es nula por inconstitucional siempre que se mantenga en los límites del estudio sobre las alternativas constitucionalmente conforme para iniciar y proseguir en un hipotético proceso constituyente de la república catalana. Y advierte y hace responsables a los poderes implicados y a sus titulares, señaladamente a la Mesa del Parlamento catalán, «de su deber de impedir o paralizar cualquier iniciativa que suponga ignorar o eludir los mandatos enunciados».

Parece que la admonición de este ATC ha tenido poca eficacia, porque con fecha 1 de agosto el TC ha admitido a trámite mediante providencia un nuevo incidente de ejecución instado por el Gobierno de la Nación (Acuerdo del Consejo de Ministros de 29 de julio de 2016) contra la Resolución 263/XI del Parla- 
mento de Cataluña de 27 de julio por la que se ratifican el informe y las conclusiones de la Comisión de Estudio del Proceso Constituyente ${ }^{20}$ por contravenir lo resuelto en la STC 259/2015. En dicha providencia, invocado por el Gobierno el artículo 161.2 CE, acuerda suspender dicha Resolución y:

«4. Conforme al art. 87.1 LOTC, sin perjuicio de la obligación que dicho precepto impone a todos los poderes públicos de cumplir las resoluciones de este Tribunal, y de acuerdo con lo pedido por la parte recurrente, notifíquese personalmente la presente resolución a la Presidenta del Parlamento de Cataluña, a los demás miembros de la Mesa del Parlamento y al Secretario General del Parlamento de Cataluña, así como al Presidente y demás miembros del Consejo de Gobierno de la Generalitat de Cataluña. Se les advierte, asimismo, de su deber de impedir o paralizar cualquier iniciativa que suponga ignorar o eludir la suspensión acordada, apercibiéndoles de las eventuales responsabilidades, incluida la penal, en las que pudieran incurrir.

5. Requerir a la Presidenta del Parlamento de Cataluña, a los demás miembros de la Mesa del Parlamento y al Secretario General del Parlamento de Cataluña para que en el plazo de veinte días hábiles emitan los correspondientes informes, a los efectos del artículo 92.4 LOTC, acerca de si las actuaciones parlamentarias que dieron lugar a la aprobación de la Resolución 263/XI del Parlamento de Cataluña, de 27 de julio de 2016, han contravenido la STC 259/2015, de 2 de diciembre y el ATC de 19 de julio de 2016.»

\section{EL INCIDENTE DE EJECUCIÓN}

El procedimiento incidental de ejecución viene regulado muy parcamente por el artículo 92 LOTC, y supletoriamente por lo dispuesto en el Capítulo IV del Título IV LJCA. La primera cuestión a dilucidar es si hay dos incidentes o uno sólo. Podría pensarse que de la lectura conjunta de los artículos 80, 87 y 92.1 y 3 , se infiere un incidente común de ejecución, en el que se prevé además la posibilidad de notificar personalmente mediante el oportuno mandamiento, requerimiento u oficio a las autoridades y empleados públicos concernidos lo acordado por el TC, so pena de incurrir en responsabilidad si no cumplen con lo notificado. Y un incidente especial de ejecución regulado en el artículo 92.4 LOTC que promovería el TC una vez comprobado que no se ha cumplido total o parcialmente con lo resuelto en un incidente previo. La interpretación sistemática de los pre-

$20 \mathrm{Su}$ texto puede consultarse en http:/www.parlament.cat/web/activitat-parlamentaria/resolucions/ index.html?p_data=12072018. Consta públicamente la citación como investigado para comparecer del Sr. Homs i Molist girada por la sala Segunda del Tribunal Supremo en la Causa Especial 3/20249/2016 relativa a los actos de preparación del proceso de participación ciudadana celebrado el 9 de noviembre de 2014 en Cataluña tras la asunción del asunto en relación con el investigado por la Sala Penal del Tribunal Supremo en su Auto de 25 de mayo de 2016 en el recurso n. ${ }^{\circ}$ 20249/2016. 
ceptos concernidos no parece sustentar esta hipótesis de la coexistencia de dos incidentes, y el propio ATC141/2016 es ejemplo de que en rigor sólo hay un único procedimiento incidental para ejecutar las resoluciones del TC.

El incidente podrá iniciarse de oficio (artículo 92.1 y 4 LOTC) o a instancia de parte (artículo 92.3 LOTC). Se entiende que las partes lo son del proceso constitucional del que trae causa la ejecución ${ }^{21}$. No obstante, cabría preguntarse si en aplicación supletoria del artículo 104.2 LJCA, cualquier persona afectada por la resolución del TC y/o su debida ejecución podría promover el incidente ante el TC. A nuestro juicio, esto es posible, máxime ante la tendencia del TEDH a extender la legitimación activa en los procesos judiciales al amparo del derecho a la defensa y a un juicio justo del artículo $6 \mathrm{CEDH}$, si, en efecto, quien no habiendo sido parte en el proceso constitucional acredita un interés legítimo en su ejecución. No se olvide que conforme al artículo 164.1 CE las resoluciones del TC «que declaren la inconstitucionalidad de una ley o de una norma con fuerza de ley y todas las que no se limiten a la estimación subjetiva de un derecho, tienen plenos efectos frente a todos». Cierto que de este precepto no cabe derivar un interés general y universal sobre el que asentar un remedo de acción popular en interés del cumplimiento de las resoluciones del TC, y por ende, de la propia CE tal cual expresa su supremacía normativa en los fallos y jurisprudencia del TC. Pero tampoco hay una razón, o al menos a nosotros se nos escapa, que impida promover el incidente de ejecución a todo sujeto público o privado que acredite la afectación directa a su esfera jurídica de una resolución del TC, aunque no haya sido parte en el proceso constitucional del que trae causa ${ }^{22}$.

El objeto del incidente debe ser, desde luego, la disposición, resolución acto, actuación, vía de hecho o inactividad que posea una conexión directa con lo que haya sido objeto del proceso constitucional y suponga, además, un manifiesto incumplimiento de lo resuelto por el TC (de su fallo y también de los fundamentos jurídicos en el que el TC lo ha sustentado) o un menoscabo evidente, material o jurídico, de su jurisdicción. Si con ocasión del cumplimiento de la resolución del TC se provocasen nuevas infracciones de la CE distintas de las que hayan motivado el fallo del TC, éstas deberán someterse al procedimiento de control de constitucionalidad que corresponda, pues el incidente de ejecución no constituye

21 La LOTC no precisa plazo alguno a partir del cual puede plantearse el incidente. Podría aplicarse entonces lo dispuesto en el artículo 104.2 LJCA (dos meses desde la comunicación de la resolución del TC).

22 Imaginemos el caso de un Ayuntamiento que opone ante la orden dictada por el Ministerio competente de suspensión y liquidación de una empresa municipal deficitaria la hipotética sentencia del TC recaída en un recurso de inconstitucionalidad que declara contraria a la CE esa norma. El Ayuntamiento en cuestión, ante la insistencia del Gobierno en aplicar la norma declarada inconstitucional, podría esgrimir la sentencia del TC como título ejecutivo frente a cualquier acción del Estado dirigida a imponer la liquidación de la empresa municipal. Y llegado el caso, si también la jurisdicción contencioso-administrativa hiciese caso omiso de la sentencia de inconstitucionalidad del TC, a nuestro juicio ese Ayuntamiento estaría legitimado para instar el incidente de ejecución pretendiendo del TC la anulación de la resolución judicial correspondiente y los actos del Estado en aplicación de una norma que ha sido declarada inconstitucional y nula. 
una nueva instancia u ocasión para realizar un control de constitucionalidad de aquellas disposiciones, resoluciones, actos, actuaciones, vías de hecho o inactividad de los obligados al cumplimiento de la resolución del TC. Tampoco parece exigible el agotamiento de una hipotética vía judicial ordinaria previa antes de acudir al incidente de ejecución ante el TC. Nada dice la LOTC sobre este particular, el TC no lo ha exigido en su práctica procesal del incidente, y parece lógico que así sea, pues es al propio TC a quien le compete velar por el cumplimiento de sus resoluciones (artículo 92.1 LOTC), sin perjuicio de que la ejecución de sus resoluciones exija la intervención de terceros, públicos o privados, y que las actuaciones de éstos sean susceptibles de control jurisdiccional ${ }^{23}$. Cosa distinta es que se formule de manera prematura el incidente, si por las condiciones de la ejecución de la resolución del TC, ésta, su ejecución, ha tenido que instarse judicialmente y aún pende la decisión judicial sobre esta cuestión. En cualquier caso, si las resoluciones del TC vinculan a todos los poderes públicos y tiene la condición de título ejecutivo (lo que apareja el despacho de ejecución inmediato), es el TC ante quien deben plantearse directa e inmediatamente las cuestiones que dimanen de la ejecución, y no la jurisdicción ordinaria, entre otras razones, porque no sólo se corre el riesgo de dilatar en el tiempo la ejecución, sino de convertir inadecuadamente en objeto del incidente, no el incumplimiento total o parcial de la resolución del TC, sino la actuación judicial en relación con esa ejecución, lo que acaso debiera dar lugar en paralelo al incidente de ejecución, y según las circunstancia del asunto, a un recurso de amparo por vulneración del derecho a la ejecución e intangibilidad de las resoluciones del TC. Así parece haberlo entendido el TC. En su ATC 107/2009, que resolvió un incidente de ejecución promovido por el Estado en relación con el ATC 335/2007 que acordaba la suspensión de una actuación de una Comunidad Autónoma, el TC entró a conocer del incidente tras la declinatoria de jurisdicción del juez de lo contencioso-administrativo ante el que se había instado la ejecución en sus términos del ATC 335/2007 (supuestamente incumplido por un Ayuntamiento), y sin que el Estado hubiese intentado recurrir, pudiendo haberlo hecho, dicha declinatoria.

El TC, admitido a trámite el incidente si «advirtiese que una resolución dictada en ejercicio de su jurisdicción pudiera estar siendo incumplida», emplazará a las partes del proceso constitucional de instancia ${ }^{24}$ para que aleguen lo que

23 El nexo de unión entre el cumplimiento y la ejecución es el título ejecutivo. El cumplimiento obligado de las decisiones del TC, de su fallo y de su doctrina, está indubitadamente establecido en el artículo 87 LOTC. Pero ese cumplimiento se hace ejecución al ser las resoluciones del TC títulos ejecutivos, de manera que en esa condición nadie podrá discutir el alcance de una resolución del TC, ni obligar a un previo ejecutivo en la vía ordinaria o a plantear un incidente de ejecución ante el TC en todo caso, porque basta con la resolución del TC para obligar a su cumplimiento. Las resoluciones del TC, en esa condición, llevan en ellas su fuerza de obligar, por tanto un deber preciso, concreto y judicialmente exigible, que de no hacerse efectivo de oficio, puede imponerse de forma forzosa.

24 Se hayan personado o no en él. La LOTC nada dice al respecto, tampoco la LJCA. No obstante, consideramos que la debida garantía de los derechos de defensa de quienes fueron o podía haber sido parte en 
consideren oportuno, al Ministerio Fiscal ${ }^{25}$, y, con arreglo al artículo 92.4 LOTC, también lo hará para evacuar informe a las «instituciones, autoridades, empleados públicos o particulares a quienes corresponda llevar a cabo» el cumplimiento de la resolución del TC $^{26}$. Es el propio TC quien fija a su voluntad el plazo común para personarse y alegar, y para evacuar el citado informe. Transcurrido ese plazo, el TC resolverá mediante auto, pues su decisión debe ser motivada, estimando o desestimando el incidente si hubiese sido promovido a instancia de parte, y si lo hubiese sido de oficio, declarando ejecutada la resolución, o bien ordenando su archivo, o acordando alguna de las medidas previstas en el artículo 92. A saber, identificar quién viene obligado a la ejecución y cómo debe ser ejecutada la resolución (lo que será sobre todo adecuado en los casos de actuaciones, vías de hecho o inactividad), la adopción de determinadas medidas para su ejecución, anular las disposiciones, resoluciones o actos que le sean contrarios, o imponer una multa coercitiva, suspender temporalmente en sus funciones al cargo público o empleado público responsables del incumplimiento, la ejecución sustitutoria o deducir testimonio de particulares. El auto que pone fin al incidente será recurrible en súplica (artículo 93 LOTC).

\section{LA DOCTRINA DEL TC SOBRE EL INCIDENTE DE EJECUCIÓN DEL ARTÍCULO 92 LOTC}

El TC ha condensado su doctrina en esta materia con estas palabras del ATC 141/2016 (FJ 2): «En efecto, conforme a la jurisprudencia constitucional (entre otros, AATC 107/2009, de 24 de marzo, FJ 2, y 177/2012, de 2 de octubre, FJ 2) los arts. 87.1 I y 92 LOTC tienen por finalidad garantizar la defensa de la posición institucional del Tribunal Constitucional y la efectividad de sus sentencias

el proceso constitucional del que trae causa el incidente de ejecución, interpretado a la luz de la jurisprudencia del TEDH sobre el artículo $6 \mathrm{CEDH}$, deben poder ser oídos en el incidente; aunque no se hayan personado en el procedimiento principal. Desde luego, nada podrán plantear sobre lo debatido en éste, y su alegato debe limitarse únicamente sobre los particulares de la ejecución de la resolución que le puso fin. De otro modo se estaría sustanciando no sólo una pretensión ajena al incidente, también o una alegación extemporánea (o incluso un recurso de amparo si esgrimen la lesión de alguno de sus derechos fundamentales).

25 Es cierto que el artículo 92 no lo establece con claridad, y bien pudiera decirse que el incidente no requiere de las alegaciones de las partes, salvo la del Ministerio Fiscal y el órgano que haya dictado la resolución, disposición o acto, en el caso de que el TC resolviese anularlas, tal y como dispone el segundo párrafo del artículo 92.1 LOTC, y el artículo 4.3 LOTC también. No obstante, debería acudirse al artículo 109 LJCA que sí regula esa audiencia previa. Por otra parte, esta es la práctica habitual del TC en los incidentes que ha resuelto hasta la fecha.

26 Haya sido o no objeto de la notificación personal del artículo 87.1 LOTC. En efecto, la citada notificación es potestativa y no condiciona la responsabilidad sobre la ejecución de las resoluciones del TC, quien tampoco está obligado a precisar en ellas quién vendría obligado a dicha ejecución (artículo 92.1 LOTC). Por tanto, ninguna de las dos circunstancias (la omisión de la identificación del responsable de la ejecución en la resolución del TC y la notificación personalizada) pueden esgrimirse como excusa para el cumplimiento en debida forma a quien corresponda de lo resuelto por el TC. 
y resoluciones, protegiendo su ámbito jurisdiccional frente a cualquier intromisión ulterior de un poder público que pudiera menoscabarla. Establecen que todos los poderes públicos están obligados al cumplimiento de lo que el Tribunal Constitucional resuelva (art. 87.1 I LOTC), así como la facultad de este Tribunal de anular cualquier acto o resolución que incumpla, menoscabe o contravenga las resoluciones dictadas en el ejercicio de su jurisdicción (art. 92.1 LOTC), ofreciendo al mismo tiempo las suficientes garantías a los órganos autores de los actos o resoluciones susceptibles de ser anuladas; junto a la necesaria motivación de la decisión del Tribunal, en forma de Auto, susceptible de recurso de súplica (art. 93.2 LOTC), se exige la previa audiencia del Ministerio Fiscal y la del órgano al que sea imputable el acto o resolución controvertido (así como la de quienes intervinieron en el proceso constitucional correspondiente, en su caso)»

El TC ha identificado dos tipos de infracciones que darían lugar al planteamiento de una incidente de ejecución del artículo 92 LOTC: los actos o disposiciones que menoscaben la eficacia jurídica o material de sus resoluciones (lo que el TC liga a lo dispuesto en el artículo 4 LOTC como precepto que ampara la intangibilidad de su jurisdicción constitucional —AATC 107/2009 FJ 4), o los que expresen un pronunciamiento que contravenga sus resoluciones (ATC 141/2016 FJ 2). Ambos son los motivos que justifican a los ojos del TC la apertura del incidente de ejecución. En él el TC velará por que, aquél que esté obligado al cumplimiento de sus resoluciones, lo haga lealmente ejecutándolas en sus propios términos sin incurrir en dilaciones indebidas o en ejecuciones simuladas o inexactas. Pudiendo reaccionar el TC frente al menoscabo o intromisión en su jurisdicción con la anulación del acto o disposición que «incumpla, menoscabe o contravenga» las resoluciones del TC, tanto su fallo como sus fundamentos. El propio TC ha mantenido que la vinculación de los poderes públicos al cumplimiento de sus resoluciones se extiende tanto al fallo de las resoluciones como a su fundamentación jurídica (SSTC 158/2004 FJ 4; 302/2005 FJ 6; AATC 273/2006 FJ 4, 120/2010 FJ 1$)^{27}$.

27 En la STC 158/2004 el TC resuelve un conflicto planteado contra la actuación del Estado mediante la firma de un Acuerdo tripartido y la convocatoria de ayudas y permisos para asistir a los cursos de formación ofertados al amparo de dicho Acuerdo que desconocerían la competencia de la CCAA en esta materia declarada en las citadas SSTC 95 y 190 de 2000. En aquella Sentencia, en la que en modo alguno se suscita una cuestión sobre la ejecución de aquellas otras, sino de cumplimiento de la doctrina del TC sobre la competencia en materia de formación continua de los trabajadores, se hace la siguiente afirmación que haría fortuna en la jurisprudencia del TC sobre el alcance de la vinculación del artículo 87.1 LOTC (FJ 4): «Por ello tenemos de nuevo que «recordar que las Sentencias de este Tribunal, de las que deriva una doctrina — la doctrina constitucional-, como señala el art. 40.2 LOTC, tienen el valor de cosa juzgada (art. 164.1 CE), de suerte que todos los poderes públicos, tal como prescribe el art. 87.1 LOTC, están obligados a dar cumplimiento a lo que el Tribunal Constitucional resuelva cualquiera que sea el procedimiento en que lo haya sido. Los mencionados preceptos determinan, por sí solos, una eficacia de las Sentencias de este Tribunal que no se proyecta únicamente respecto de los hechos pretéritos que fueron el objeto del proceso, sino que se extiende de algún modo hacia el futuro» (STC 230/2003, FJ 6)... Al respecto, hay que añadir que, según hemos declarado ya respecto de las manifestaciones ob iter u ob iter dicta (sic), «una cosa es el puro dictum 'observación al pasar', 
Dice el ATC 107/2009 (FJ 4): «Tal cuestión deberemos resolverla aplicando los criterios consolidados en la doctrina constitucional en cuanto al art. 92 LOTC, pues corresponde a este Tribunal resolver, en su caso, las incidencias de ejecución de sus propias resoluciones. A tal efecto, debe velar para que las Sentencias y decisiones que adopte se ejecuten, por quien resulte obligado a ello, en sus propios términos y de la manera más diligente posible, evitando que se produzcan incumplimientos simulados o inexactos y dilaciones indebidas en la ejecución, sin que deba olvidarse que el propio art. 92 LOTC permite que este Tribunal disponga en la Sentencia o resolución que dicte quién ha de ejecutarla».

En toda su jurisprudencia sobre el incidente de ejecución del artículo 92 LOTC, el TC insiste de forma reiterada en que debe haber una identidad de razón y fundamento entre el objeto del proceso constitucional resuelto previamente por el TC (que puede ser un incidente también, pues cabe plantear el incidente de ejecución respecto de una medida cautelar, como fue el caso del ATC 12/2001 o del ATC 107/2009) y el objeto del incidente de ejecución. El TC ha examinado escrupulosamente esa conexión y ha rechazado la pretensión de plantear por medio del incidente pretensiones que no estaban contenidas en las que originaron el proceso del que trae causa dicho incidente o el examen de la constitucionalidad de las actuaciones de un Poder público en el cumplimiento de una resolución del TC si ese juicio no deriva de la obligación de llevar a su debido cumplimiento lo acordado en esa resolución ${ }^{28}$.

no trascendente ni como argumento complementario, y otra el dictum argumentativo que se relaciona más o menos lateralmente con las razones decisivas del fallo. En este caso esos dicta son opiniones del Juez o Tribunal con propia eficacia y si bien no integran la cosa juzgada (ésta se configura en el fallo y su fundamento determinante), sí valen como valoraciones jurídicas del Tribunal y constituyen, en cierto modo y buena medida, antecedentes dotados de auctoritas. Esta interpretación del Tribunal, en el ámbito de su específica competencia, constituye por ello regla vinculante (arts. 164 CE y 38 LOTC)» (STC 6/1991, de 25 de enero, FJ 4)...Por tanto, la especial vinculación que para todos los poderes públicos tienen las Sentencias de este Tribunal no se limita, en contra de lo sostenido por el Abogado del Estado, al contenido del fallo, sino que se extiende a la correspondiente fundamentación jurídica, en especial a la que contiene los criterios que conducen a la ratio decidendi».

28 Un buen ejemplo de la cognición limitada del incidente y esa identidad entre lo resuelto en el proceso y lo que se pretende ejecutar es el ATC 107/2009 es paradigmático Este Auto desestima el incidente promovido por el Abogado del Estado respecto de la suspensión de una resolución de la Administración de una Comunidad Autónoma en relación con las obras de una planta desalinizadora. La autoridad administrativa autonómica había paralizado las obras de la planta al estar disconforme con su ubicación, y el Estado había planteado un conflicto positivo de competencias contra dicha resolución esgrimiendo el artículo 161.2 CE con el objeto de levantar la suspensión autonómica y permitir la continuación de las obras de la planta. El TC decretó en consecuencia la suspensión de la resolución paralizadora de las obras, lo que tendría el efecto de que éstas siguiesen su curso. Posteriormente el Ayuntamiento en el que se realizaban las obras decretó la paralización del bombeo de aguas con ocasión de sus trabajos de ejecución, que estaba afectando a una calle y a la vereda de una carretera nacional a su paso por el término municipal. El Estado impugnó ante el contencioso-administrativo los decretos municipales, y tras la declinatoria de jurisdicción del juez ordinario al considerar que el competente era el TC por entender que se trataba de un incidente de ejecución de su Auto de suspensión dictado al amparo del artículo 161.2 LOTC, la Abogacía del Estado instó dicho incidente ante el alto tribunal al considerar que los decretos municipales incumplían las suspensión acodada por el TC de la resolución autonómica que paralizaba las obras de la planta. El TC sin embargo consideró que los decretos munici- 
Sin embargo, a pesar de que éste es el cuerpo central de la doctrina del TC sobre el artículo 92 LOTC, lo cierto es que ha matizado su alcance y sentido en función del proceso constitucional al que se anudaba el incidente de ejecución. Especialmente rica en su escasez es la jurisprudencia en relación con los recursos de amparo, lo que es lógico en la medida en que éstos cuando son estimatorios pueden incidir sobre situaciones jurídicas individuales concretas o sobre realidades materiales que se pueden ver en ambos casos alteradas por lo acordado por el TC.

\section{Ejecutar amparos}

No cabe duda de que es el proceso constitucional en el que mayor relevancia posee el incidente de ejecución, en la medida en que, por una parte, las sentencias desestimatorias o las que no se limiten a la estimación subjetiva de un derecho poseen plenos efectos frente a todos (artículo $164 \mathrm{CE}$ ); y por otro lado, el fallo de un amparo puede declarar la nulidad de la decisión, acto o resolución que hayan impedido el pleno ejercicio de los derechos o libertades protegidos, con determinación, en su caso, de la extensión de sus efectos, reconocer el derecho o libertad pública, de conformidad con su contenido constitucionalmente declarado, y/o restablecer al recurrente en la integridad de su derecho o libertad con la adopción de las medidas apropiadas, en su caso, para su conservación (artículo 55 LOTC). El TC dispone en la resolución de un amparo de un amplio abanico de posibilidades que le permiten precisar el alcance de los efectos de su decisión y ordenar la adopción de las medidas que considere convenientes para el mejor reconocimiento, restablecimiento y garantía efectiva del derecho fundamental lesionado. En puridad, cumplir con lo resuelto en un amparo (incluso si es desestimatorio, en la medida en que afecta a la otra parte del proceso de instancia) no es sólo responsabilidad de la jurisdicción ordinaria ante la que se haya seguido el pertinente y previo proceso judicial, porque en unos casos el obligado será la Administración o Poder público infractor (artículos 42 y 43 LOTC), y en otros, en efecto, será el órgano judicial en la medida en que sea él el infractor y no se limite a ser la instancia judicial revisora de la hipotética infracción cometida por un tercero.

El problema de la ejecución de los amparos, y así resulta de la propia jurisprudencia del TC, es precisar en cada caso si la controversia suscitada al hilo del cumplimiento de un resolución del TC recaída en un proceso de amparo debe ser sustanciada en un incidente de ejecución o, sin embargo, debe ser objeto de un nuevo recurso de amparo ${ }^{29}$. Lo cierto es que el TC a lo largo de su jurisprudencia

pales sólo ordenaban la paralización del bombeo de agua por las razones expuestas y no la obra en su conjunto, por lo que los decretos municipales no guardaban relación ni suponían una contravención de su Auto de suspensión, pues la obra podía seguir su curso a pesar de que esos bombeos estaban paralizados.

29 Un análisis desde otra perspectiva de la ejecución de los amparos según se trate de resoluciones declarativas, constitutivas o de condena, puede verse en Javier Salas/Valeriano Palomino, ob.cit., pp. 99 y ss. 
ha tramitado como nuevos amparos quejas relativas a hipotéticos incumplimientos de previas sentencia estimatorias de recursos de amparo, sin justificar técnicamente la causa de este proceder, aunque lo controvertido en el caso no fuese la lesión de un nuevo derecho fundamental, sino el modo en el que el sujeto obligado a cumplir con la sentencia de amparo lo ha hecho, lo que en rigor hubiera debido resolverse en un incidente de ejecución del artículo 92 LOTC $^{30}$.

Es evidente que el incidente de ejecución no es el cauce adecuado para plantear pretensiones no contenidas en el recurso de amparo original y que soportan lo resuelto en la sentencia de amparo del TC. Como ha dicho el TC, la ejecución queda constreñida y delimitada por el petitum de la demanda de amparo (ATC $731 / 1984)^{31}$. En consecuencia, aunque todo incidente de ejecución supone una

30 No se olvide que el incumplimiento por parte de la jurisdicción ordinaria objeto de un posible incidente de ejecución no es el que el TC considera uno de los casos de trascendencia constitucional que justificarían la admisibilidad de un recurso de amparo, a tenor de lo sentado en la STC 155/2009, FJ 2: «d) o si la vulneración del derecho fundamental traiga causa de una reiterada interpretación jurisprudencial de la ley que el Tribunal Constitucional considere lesiva del derecho fundamental y crea necesario proclamar otra interpretación conforme a la Constitución; e) o bien cuando la doctrina del Tribunal Constitucional sobre el derecho fundamental que se alega en el recurso esté siendo incumplida de modo general y reiterado por la jurisdicción ordinaria, o existan resoluciones judiciales contradictorias sobre el derecho fundamental, ya sea interpretando de manera distinta la doctrina constitucional, ya sea aplicándola en unos casos y desconociéndola en otros», y especialmente el así descrito «f) o en el caso de que un órgano judicial incurra en una negativa manifiesta de deber de acatamiento de la doctrina del Tribunal Constitucional (art. 5 de la Ley Orgánica del Poder Judicial: LOPJ)». Todos ellos son incumplimientos que contarían lo dispuesto en el artículo $164 \mathrm{CE}$, y en los artículos 40.2 y 87.1 LOTC, y sólo serían susceptibles de fundar un incidente de ejecución y no un recurso de amparo, si la «negativa manifiesta» del órgano jurisdiccional lo es a lo resuelto en concreto en una sentencia (o auto si es suspensivo) del TC recaída en un amparo y, o bien es el órgano judicial al que por mandato expreso del TC o a resultas de lo resuelto, le cumple llevar a debido efecto su fallo y fundamentos en los que se sostiene, o bien si, no siendo el obligado en primer término a cumplir con la resuelto por el TC (caso de los amparos de los artículos 42 y 43 LOTC), pero conociese del caso, procediese negando o con manifiesto desconocimiento de lo fallado por el TC. La propia dicción del apartado 2 del artículo 40 LOTC (reforzada por la de los artículos 5 , 6, 7 y 8 Ley Orgánica 6/1985, de 1 de julio, del Poder Judicial) no puede ser más clara: «En todo caso, la jurisprudencia de los tribunales de justicia recaída sobre leyes, disposiciones o actos enjuiciados por el Tribunal Constitucional habrá de entenderse corregida por la doctrina derivada de las sentencias y autos que resuelvan los procesos constitucionales». La cuestión constitucionalmente relevante a los efectos de admitir un amparo es la elusión por la jurisdicción ordinaria de la doctrina del TC sobre un derecho fundamental y no el incumplimiento de un fallo concreto del TC.

31 En dicho Auto el TC desestima un incidente de ejecución en el que el amparado pretendía ex novo una repetición de la elecciones que no había pretendido en su demanda de amparo de cuya estimación traía causa el incidente del artículo 92 LOTC. Este Auto es comentado por Javier Salas/Valeriano Palomino, ob. cit., pp. 103 y ss., donde se hacen eco del Voto Particular discrepante del Magistrado Rubio Llorente. El TC en su ATC 12/2001 sostuvo que no se trataba de un caso de incumplimiento de una de sus sentencias de amparo la desestimación de una petición de indemnización formulada por el amparado en el procedimiento judicial ordinario instado para el debido cumplimiento de la resolución del TC (el recurrente había obtenido una sentencia estimatoria de su amparo contra la Administración, y al tiempo que instó a ésta judicialmente para que diese debido cumplimiento a la sentencia de amparo, solicitó una indemnización por los daños patrimoniales que le había ocasionado el hecho de haber tenido que pleitear contra la Administración). El TC dice con claridad que «En efecto, la solicitud de indemnización ante la Administración autonómica como consecuencia de la estimación de su demanda de amparo, cuya denegación el Sr... considera que supone una inejecución de la STC 48/1998 de 2 de marzo, no es algo de lo que pueda conocer este Tribunal a través del art. 92 LOTC» (FJ 2). 
posible vulneración del derecho a la ejecución y a la intangibilidad de las resoluciones del TC (por todos, ATC 90/2008 FJ 2) o incluso del derecho a una resolución judicial motivada, no por ello cabe suscitar un nuevo amparo con tal motivo, pues es justo el incidente de ejecución del artículo 92 LOTC el instrumento que el legislador ha puesto en manos del TC para salvaguardar la intangibilidad y la obligatoriedad de sus pronunciamiento. Sin embargo, el TC no siempre ha obrado de esta forma.

El TC ha conocido y resuelto casos de incumplimiento de sus resoluciones recaídas en procesos de amparo por medio de un nuevo recurso de amparo por vulneración del artículo 24.1 CE en su manifestación del derecho a la intangibilidad de sus resoluciones contra la resolución judicial que las incumplió o desconoció. El TC no hace cuestión (al menos expresamente) sobre si lo procedente en esto casos es acudir a un nuevo amparo o debería instarse un incidente de ejecución del amparo inicialmente estimado. Probablemente fue la STC 159/1987 en relación con el amparo otorgado por vulneración de la libertad de expresión en la STC 104/1986 la primera en que el TC aceptó sin más reflexión la vía del amparo por vulneración del artículo 24 en el caso de resoluciones judiciales que desoían las previas del TC ${ }^{32}$. Así también en las SSTC 227/2001 (en relación con una orden de extradición anulada por la previa STC 141/1998), 153/2004 (respecto de la STC 202/1999 en materia de protección de datos) y la STC 302/2005. En esta última, en relación con la debida ejecución de la anterior STC 213/2003, amparó a los recurrentes por infracción del artículo 24.1 CE en su manifestación del derecho a una resolución motivada y fundada en Derecho, y le recordó a la jurisdicción ordinaria (FJ 6):

«Todo lo anteriormente expuesto conduce a la estimación de la demanda de amparo. La reposición de los recurrentes en su derecho fundamental vulnerado determina la declaración de nulidad de las resoluciones impugnadas fundadas en una motivación arbitraria y manifiestamente irrazonable, y la retroacción del procedimiento para que el órgano judicial se pronuncie nuevamente sobre la admisión del aval aportado con escrupuloso respeto a las decisiones de este Tribunal Constitucional (arts. 87 LOTC y 5.1 de la Ley Orgánica del Poder Judicial), bien acordando la admisión del aval, con ejecución de la medida cautelar adoptada, o bien acordando su inadmisión por causa distinta de la extemporaneidad de su presentación.

Por último debemos recordar que, de conformidad con lo ordenado en el art. 87.1 LOTC, los órganos judiciales están obligados al cumplimiento de lo que este Tribunal Constitucional resuelva, no pudiendo, en consecuencia, desatender a lo declarado y decidido por el mismo. En algunas ocasiones el cumplimiento por el

32 Además, el TC planteó este asunto como una posible contravención de la fuerza de cosa juzgada de la STC 104/1986 de la que traía causa los autos de la STC 159/1987. 
órgano judicial de una Sentencia de este Tribunal puede requerir una interpretación del alcance de la misma, a fin de dar un cabal cumplimiento a lo resuelto en ella y adoptar, en consecuencia, las medidas pertinentes para hacer efectivo el derecho fundamental reconocido frente a la violación de la que fue objeto. Pero semejante consideración y aplicación por el órgano judicial no puede llevar, sin embargo, como es claro, ni a contrariar lo establecido en ella ni a dictar resoluciones que menoscaben la eficacia de la situación jurídica subjetiva allí declarada (SSTC 159/1987, de 26 de octubre, FJ 3; 227/2001, de 26 de noviembre, FJ 6; 153/2004, de 20 de septiembre, FJ 3; y AATC 134/1992, de 25 de mayo, FJ 2; 220/2000, de 2 de octubre, FJ 1; 19/2001, de 30 de enero, FJ 2). Por lo demás, la especial vinculación que para todos los poderes públicos tienen las Sentencias de este Tribunal no se limita al contenido del fallo, sino que se extiende a la correspondiente fundamentación jurídica, en especial a la que contiene los criterios que conducen a la ratio decidendi (STC 158/2004, de 21 de septiembre, FJ 4)».

Otro caso bien conocido y que dio lugar a un sonado conflicto con el TS fue el de la STC 186/2001, en la que el TC da respuesta mediante la estimación de un nuevo amparo al defectuoso cumplimiento por el TC de lo fallado en su STC $115 / 2000$, que declaró la lesión del derecho a la intimidad de la recurrente ${ }^{33}$. Similar a este caso fue también el de la STC 122/2003 donde se admite y estima un amparo con ocasión del cumplimiento por la jurisdicción ordinaria de la STC 96/1999. El TC consideró que la jurisdicción ordinaria había incurrido en una manifiesta incongruencia omisiva lesiva del derecho fundamental a la tutela judicial del amparado, incumpliendo con este comportamiento lo fallado anteriormente por el TC, lo que fue paladinamente desoído y orillado por el juez de instancia. En ninguno de ellos, el TC se planteó la cuestión sobre si el cauce procesal adecuado para resolver las quejas de los recurrente previamente amparados por sendas decisiones del TC debió ser el incidente de ejecución y no la admisión y resolución de sendos nuevos amparos (ni siquiera lo hizo el Voto Particular que acompañó a la STC 186/2001) ${ }^{34}$. En otras ocasiones el TC no ha tenido reparo alguno en resolver las impugnaciones de los actos y resoluciones dictadas con

33 El TC razona en este caso que el TS no había motivado la revisión del quantum indemnizatorio como consecuencia del nuevo recurso de casación planteado por la amparada en cumplimiento de lo fallado en la STC 115/2000 y además había vulnerado el derecho a la intimidad de la recurrente una vez más al haberse apartado de la doctrina que sobre este derecho ha sentado el TC. El TC en este caso acordó la nulidad de la Sentencia recurrida de la Sala Primera del Tribunal Supremo «y, a los fines indicados, declarar que, en cuanto al quantum indemnizatorio, ha de estarse en ejecución de nuestro fallo a la cantidad acordada en concepto de indemnización por el fallo de la Sentencia de la Audiencia Provincial de Barcelona de 12 de enero de 1993, cuya fundamentación resulta acorde con las exigencias del derecho fundamental expresadas en la STC 115/2000» (FJ 9).

34 Véanse también los casos de la STC 240/2000, que resuelve desestimatoriamente un amparo impetrado contra una sentencia de la jurisdicción ordinaria a la que imputa la lesión del artículo 24.1 CE por no cumplir con lo ordenado n la STC 117/1996; o de la STC 241/2000 en relación con el reconocimiento de una indemnización y la reformatio in peius, en la que según la amparado incurrió la jurisdicción ordinaria al dictar nueva resolución tras la estimación de su amparo mediante la STC 59/1997. En este caso el TC desestimó el amparo; aunque tácitamente vino a concluir que si la resolución de la jurisdicción ordinaria dictada en ejecu- 
ocasión o en ejecución de las suyas recaídas en amparo mediante incidentes de ejecución promovidos por el amparado ${ }^{35}$. En el caso del ATC 273/2006, los recurrentes plantearon una nueva demanda de amparo contra sendas resoluciones judiciales que a su juicio no habían ejecutado en su debida forma la STC 84/2002, que había estimado anteriormente su recurso en defensa de su derecho a la libertad sindical. La Sección Primera del TC inadmitió el recurso formulado en el que se invocaba la lesión de los derechos fundamentales a la libertad sindical y a la tutela judicial efectiva en su manifestación de derecho al proceso con todas las garantías y a la ejecución de las sentencias en sus propios términos, y lo elevó a la Sala para su tramitación como un incidente de ejecución del artículo 92 LOTC $^{36}$.

El TC ha hecho el esfuerzo de delimitar los ámbitos reservados al recurso de amparo y al incidente de ejecución de un amparo anterior en el ATC 120/2010. Este Auto trae su causa de la STC 25/2008, en la que se declaró vulnerado el derecho de acceso al proceso de los recurrentes al no haberles reconocido su legitimación activa en el proceso de instancia. Dice el Auto en su FJ 1:

«Este Tribunal Constitucional ha proclamado en numerosas ocasiones que el derecho a la ejecución de las Sentencias firmes en sus propios términos y el respeto a la firmeza y a la intangibilidad de las situaciones jurídicas en ellas declaradas se

ción de una del TC incurría en reformatio in peius lo pertinente sería plantear un amparo frente a esta resolución, pues habría conculcado un derecho distinto al que resultó amparado con antelación.

35 Ese fue el caso del ATC 134/1992, que trae causa de la STC 140/1991 que anula las sentencias penales que condenaban al amparado por lesión de su derecho a la presunción de inocencia. En este caso, el TC afirmó que su fallo en la STC 140/1991 declaró la lesión del derecho a la presunción de inocencia del amparado y anuló las sentencias condenatorias sin ordenar la retroacción de las actuaciones, por lo que, sin necesidades de ulteriores actuaciones, no cabía repetir el juicio contra el recurrente. Por esta razón estimó el incidente de ejecución y ordenó la comunicación a los órganos judiciales ordinarios de que no era posible reabrir juicio por los mismos hechos contra el amparado. De interés resulta también el caso del ATC 220/2000 por el que se resuelve un incidente de ejecución en relación con un Auto del TC de suspensión (ATC 247/1999) relativo a un lanzamiento de una vivienda. El caso es que cuando el TC acordó la suspensión del lanzamiento, éste ya se había producido, por lo que enterada la jurisdicción ordinaria de la suspensión, acordó ordenar la devolución de la posesión de la vivienda al recurrente de amparo, a lo que se opuso la contraparte dictándose nuevas resoluciones judiciales dejando sin efecto dicho reintegro de la posesión. El TC estima el incidente, recrimina a la jurisdicción de instancia el no haber adoptado medida cautelar alguna para proteger al amparado de posible perjuicios futuros, lo que podría haber dejado sin eficacia el recurso de amparo si llegara a estimarse, limita los efectos suspensivos de la interposición del amparo acordados en el ATC 247/1999 a las actuaciones futuras que puedan agravar de forma irreparable el perjuicio ya sufrido por el recurrente, y ordena la anotación preventiva en el Registro de la Propiedad de la demanda de amparo.

36 El TC estimó el incidente al concluir que las resoluciones judiciales de instancia habían contrariado gravemente lo resuelto por el TC, tanto su fallo y las razones que lo fundaron, al negar la vulneración del derecho a la libertad sindical de los amparados a pesar de que esa vulneración había sido declarada en la STC 84/2002. En el fallo el TC anula las resoluciones judiciales atacadas por considerar que no ejecutan adecuadamente lo dispuesto en la STC 84/2002, y ordena la retroacción de las actuaciones judiciales (un recurso de súplica) del que trae causa inmediata el incidente de ejecución para que se resuelvan las pretensiones de las partes partiendo de la lesión del derecho a la libertad sindical en los términos que así fue declarada en la STC 84/2002. El ATC 151/2001 también aborda un caso de inejecución en sus propios términos de la STC 74/1998 relativa a la lesión del derecho a la libertad sindical en relación con una discriminación salarial. En este caso el ATC anula la sentencia de instancia y ordena que se dicte una nueva en el sentido expuesto en su FJ 6. 
predica, no sólo de las resoluciones dictadas por los órganos judiciales, sino también de las propias Sentencias de este Tribunal Constitucional. Dicha garantía deriva en este ámbito, tanto de la virtualidad del derecho fundamental a la tutela judicial efectiva (art. 24.1 CE), del que no puede obviamente quedar excluida nuestra propia jurisdicción, como de lo dispuesto al efecto en el art. 87.1 LOTC (así, en Sentencias de recursos de amparo: SSTC 159/1987, de 26 de octubre, FJ 2; y 153/2004, de 20 de septiembre, FFJJ 1 y 3; AATC 151/2001, de 13 de junio, FJ 7; 459/2007, de 17 de diciembre, FJ 2; y 90/2008, de 14 de abril, FJ 2). Por lo demás la vinculación de los poderes públicos a nuestras Sentencias se extiende tanto al fallo como a su fundamentación jurídica (SSTC 158/2004, de 21 de septiembre, FJ 4; 302/2005, de 21 de noviembre, FJ 6; ATC 273/2006, de 17 de julio, FJ 4). Consecuentemente, y tratándose de recursos de amparo, la inejecución por los Tribunales ordinarios de nuestras Sentencias acarrea, no sólo la vulneración de la garantía a la ejecución e intangibilidad de nuestras decisiones, sino también la del derecho fundamental cuyo reconocimiento y restitución habían sido acordados por este Tribunal en el fallo correspondiente (AATC 79/2002, de 20 de mayo, FJ 4; y 273/2006, de 17 de julio, FJ 4).

En orden al cumplimiento del mencionado derecho a la ejecución e intangibilidad de nuestras decisiones por los Tribunales de Justicia hemos señalado que «en algunas ocasiones el cumplimiento por el órgano judicial de una Sentencia de este Tribunal puede requerir una interpretación del alcance de la misma, a fin de dar un cabal cumplimiento a lo resuelto en ella y adoptar, en consecuencia, las medidas pertinentes para hacer efectivo el derecho fundamental reconocido frente a la violación de la que fue objeto. Pero semejante consideración y aplicación por el órgano judicial no puede llevar, sin embargo, como es claro, ni a contrariar lo establecido en ella ni a dictar resoluciones que menoscaben la eficacia de la situación jurídica subjetiva allí declarada» (STC 302/2005, de 21 de noviembre, FJ 6; en similares términos SSTC 159/1987, de 26 de octubre, FJ 3; 227/2001, de 26 de noviembre, FJ 6; y 153/2004, de 20 de septiembre, FJ 3; AATC 134/1992, de 25 de mayo, FJ 2; y 273/2006, de 17 de julio, FJ 4). Lo que ha de examinarse al cotejar el contenido de nuestra Sentencia con la resolución jurisdiccional dictada en su ejecución no es tanto, ni necesariamente, la estricta correspondencia literal de los términos entre ambas, sino que la resolución judicial posterior no incurra en alguna de estas dos situaciones proscritas por nuestra doctrina (pronunciamiento contrario a nuestra decisión o intento de menoscabar la eficacia 'jurídica o material' de lo que hemos resuelto y mandado).

Por otra parte, el ámbito de conocimiento del incidente de ejecución previsto en el art. 92 LOTC "se circunscribe exclusivamente a determinar si la Sentencia del Tribunal Constitucional dictada con ocasión de un recurso de amparo ha sido correctamente ejecutada, sin que, en modo alguno, pueda extenderse a cualesquiera otras pretensiones mantenidas por la parte recurrente ante la jurisdicción ordinaria" (AATC 52/2004, de 23 de febrero, FJ 2; y 323/2008, de 20 de octubre, FJ 2).»

Para el TC en este Auto la línea divisoria entre el amparo y el incidente está en determinar si ha habido vulneración de un derecho fundamental nuevo y no esgrimido en el proceso constitucional de origen, o lo vulnerado es lo resuelto por 
el TC. En el primer caso, lo adecuado es plantear un nuevo recurso de amparo, cuyo objeto debe ser esa nueva lesión de un derecho fundamental y no lo fallado por el TC anteriormente; aunque esa lesión se haya originado con ocasión del cumplimiento de ese fallo previo del TC. En el caso resuelto por el ATC 120/2010, el TC razonó que los amparados lo que suscitaron con el incidente de ejecución no fue que la jurisdicción ordinaria haya incumplido el mandato de la Sentencia de amparo que anulaba sus resoluciones y retrotraía las actuaciones judiciales, sino que, una vez hecho esto, la jurisdicción ordinaria al dictar nueva sentencia había vulnerado un derecho fundamental distinto (derecho fundamental a la motivación como consecuencia de un error cometido por el tribunal ordinario) al que fue objeto de la Sentencia del TC que se estaba tratando de cumplir (el derecho fundamental de acceso al proceso):

«De ello debemos concluir que la cuestión "constitucional" planteada por vía del art. 92 LOTC (inejecución de un pronunciamiento del Tribunal) es exclusivamente la relativa a la condena en costas a la Administración (o aplicación del art. 10.3 Ley 62/1978 e imposición o aplicación del art. 139.1 LJCA y absolución), la cual resulta - a todas luces - una materia de legalidad ordinaria (y así lo confirmarían, entre otras, las SSTC 134/1990, de 19 de julio, FJ 5; 190/1993, de 14 de junio, FJ 4; 41/1994, de 15 de febrero, FJ 2; 48/1994, de 16 de febrero, FJ 2; 46/1995, de 14 de febrero, FJ 3; 8/1999, de 8 de febrero, FJ 1; 191/2001, de 1 de octubre, FJ 6; 170/2002, de 30 de septiembre, FJ 17; y 107/2006, de 3 de abril, FJ 3, o la ulteriormente citada por el Ministerio Fiscal, de STC 172/2009, de 9 de julio). Y, por otra parte, que la causa petendi constitucional del recurrente reside en la imputación de un error en dicha fundamentación legal de las costas, cuestión que tampoco debe ser objeto de nuestro pronunciamiento, primero, porque al tratarse de otro derecho fundamental diferenciado del inicialmente invocado en el recurso de amparo n. ${ }^{\circ}$ 6540-2004, correspondería haberla introducido por medio de un amparo autónomo, y no como un incidente del art. 92 LOTC (lo cual —a su vez-implicaría óbices de admisibilidad); y segundo, que la fundamentación de la condena (o no) en costas, es una tema estrictamente de legalidad, en el que el Tribunal ha de respetar la integridad competencial de la jurisdicción ordinaria "salvo incongruencia, arbitrariedad o irrazonabilidad" (por todas SSTC 232/2007, de 5 de noviembre, FJ 3, y 51/2009, de 23 de febrero, FJ 2 -cuestión distinta del "error patente" alegado, STC 109/2006, de 3 de abril); sin que en este supuesto pueda apreciarse la reseñada irrazonabilidad en la opción por la aplicación de un determinado precepto legal relativo a las costas (vid. STC223/2005, de 12 de septiembre, FJ 2), aunque sea jurídicamente desacertado (por todas STC 172/2009, de 9 de julio, FJ 4) (FJ 2).»

El TC ya había advertido en la STC 2/1990 (último párrafo de su FJ 1) que si la queja del amparado lo era sobre la forma en la que se había cumplido la sentencia del TC, aunque se invocase el derecho fundamental a la tutela judicial efectiva en su manifestación del derecho a la ejecución, el cauce procesal adecuado para reaccionar frente a ese incumplimiento no era el planteamiento de un nuevo recurso de amparo del artículo 44 LOTC por infracción del artículo $24 \mathrm{CE}$, sino 
suscitar un incidente del artículo 92 LOTC. En este mismo sentido se pronunciaron los AATC 18/2000 y 19/2000 que inadmitieron sendos recursos de amparo señalando que algunas de las vulneraciones planteadas en ellos hubieran debido sustanciarse en un incidente de ejecución y no a una nueva demanda de amparo.

No parece que el TC, a pesar de lo dicho en la STC 2/1990 o en el ATC 120/2010 tenga un criterio claro sobre el modo de proceder adecuado en el caso de que se traiga a su conocimiento la discrepancia sobre el cumplimiento de una de sus resoluciones. El TC, salvo en contadísimas ocasiones, parece dejarse llevar por la voluntad del recurrente y la elección que éste haga del cauce procesal, sin hacer cuestión sobre este particular. Sin embargo, el asunto no es baladí. En primer lugar, porque el alcance de un fallo en una sentencia de amparo (artículo 164 CE y 55 LOTC) no es similar a lo resuelto mediante el auto que ponga fin al incidente de ejecución (artículo 92 LOTC). Y en segundo lugar, porque el amparo permitiría al TC examinar materialmente la lesión de un derecho fundamental, mientras que en el incidente en rigor esto no sería posible porque su finalidad es comprobar si en efecto su resolución ha resultado incumplida en todo o en parte, y remediar el incumplimiento, pero no pronunciarse sobre hipotéticas nuevas lesiones de derechos fundamentales ocurridas con ocasión del cumplimiento de sus resoluciones.

\section{La ejecución en los procesos de control de constitucionalidad de normas}

Las resoluciones del TC en los procesos de control de la constitucionalidad de las normas con rango de ley tienen efectos declarativos ${ }^{37}$. La declaración de inconstitucionalidad de una norma agota sus efectos con su sola publicación, sin necesidad de ulteriores actuaciones. El ATC 309/1987 ha sido claro en este extremo:

«Además de ello ha de señalarse que las Sentencias declaratorias de inconstitucionalidad de las leyes, que determinan el efecto de invalidación de las mismas, no tienen ejecución por la justicia constitucional. Producen efectos generales y vinculan a todos los poderes públicos, como dice el art. 38 de la LOTC, pero no requieren una especial actividad de ejecución por parte del Tribunal. Es cierto que el art. 92 LOTC permite el Tribunal que éste disponga en su Sentencia o en la resolución, o en actos posteriores, quién ha de ejecutarla y, en su caso, resolver, los incidentes de ejecución, mas no debe olvidarse que el citado artículo se encuentra contenido en las disposiciones comunes sobre procedimiento y que debe, por tanto interpretarse en

37 Sigue siendo una referencia inexcusable sobre la tipología de fallos en este tipo de procesos y su relación con la forma en que vinculan el trabajo de Jiménez Campo, Javier, «La declaración de inconstitucionalidad de la ley», Rubio Llorente/Jiménez CAmpo, Estudios sobre jurisdicción constitucional, McGraw Hill, Madrid, 1998, pp. 109 y ss., pp. 121 y ss. También puede verse el de RoTH, W., «Grundlage und Grenzen von Übergangsanordnungen des Bundesverfassungsgerichts zur Bewältigung möglicher Folgeprobleme seiner Entscheidungen», Archiv des öffentlichen Rechts, Bd. 124, 1999, pp. 470 y ss., pp. 476 y ss.

UNED. Teoría y Realidad Constitucional, núm. 38, 2016, pp. 643-682 
función de las peculiaridades de los diversos procedimientos posibles ante este Tribunal, quedando, por lo ya indicado, excluida su aplicación en lo que afecta a las cuestiones de inconstitucionalidad (FJ 2)».

Por lo tanto, el alcance de las resoluciones del TC en este tipo de procesos es idéntico al de la publicación de las normas con rango de ley. Su expulsión del ordenamiento jurídico las inhabilita con carácter general como soporte normativo para dar amparo a disposiciones, resoluciones, actos o actuaciones de los Poderes públicos. En unos casos, esa ausencia de conexión con el caso concreto (procesos de control abstracto), y en otros, la circunstancia de que la jurisdicción ordinaria esté obligada a aplicar la norma con rango de ley o no, según el caso, en el proceso del que conoce una vez resuelta por el TC la cuestión de inconstitucionalidad que le fue planteada, hace difícil, en efecto, identificar qué casos serían aptos para someter al incidente del artículo 92 LOTC. No obstante, en estas páginas se discrepa de esa afirmación del TC que excluye el artículo 92 LOTC de las cuestiones de inconstitucionalidad, en la medida en que consideramos que sería el cauce procesal adecuado a disposición de las partes en el proceso ordinario, si el juez de instancia se negará a dar cumplimiento, o lo hiciese defectuosamente, a lo acordado por el TC en la cuestión de inconstitucionalidad que le elevó.

La incógnita que suscita este tipo de procesos es si sería posible plantear a través del incidente de ejecución la nulidad de una norma con rango de ley cuyo contenido fuese contrario a lo resuelto previamente por el TC. ¿Podría el TC anular una futura e hipotética ley catalana por la que se regula el proceso constituyente catalán en aplicación de las Resoluciones 1/XI, 5/XI y 263/XI, en un incidente de ejecución por incumplimiento de la STC 259/2015?

La reciente BVerfGE de 7 de junio de 2016, 2 BvL 3/12 et altrii, ha abordado una cuestión muy similar a la aquí planteada ${ }^{38}$. En esa ocasión el BVerfG se pronunció sobre un incidente de ejecución promovido al amparo del $\S 35$ BVerfGG en el que se consideraba que el Legislador de un Estado federado había incumplido lo fallado en la BVerfGE 139, 64 <11 > que le imponía la obligación de modificar cierta ley para hacerla «constitucionalmente conforme» con «efectos a más tardar el 1 de enero de 2016». Lo que así hizo el Estado federado que aprobó y publicó una ley de reforma de la constitucionalmente controvertida en diciembre de 2015. Sin embargo, los promotores del incidente consideraron que la reforma legislativa no había cumplido con los criterios expresados en la BVerfGE 139, 64, planteando un incidnete de ejecución. El BverfG rechazó el incidente por inadmisible. El alto tribunal alemán señala que lo planteado por los promotores del incidente en realidad no es una discrepancia en la forma en la que se ha

38 Puede consultarse un elenco de casos similares en los que el BVerfG ha resuelto incidentes de ejecución en relación con actuaciones del legislador en Bethge, Werner, ob. cit., pp. 18 y ss., y 32 y ss., donde analiza también las distintas variantes de pronunciamientos en los procesos de control de constitucionalidad y sus formas de ejecución. 
cumplido con lo resuelto en su anterior decisión, sino sobre la constitucionalidad de la controvertida ley de reforma, lo que debe sustanciarse a través del pertinente proceso de control de constitucionalidad de las normas con rango de ley. Dice el BVerfG:

«Sin embargo, no puede ser el propósito del § 35 BVerfGG, poner a disposición del beneficiado por un proceso de control de constitucionalidad anterior un nuevo proceso mediante un recurso legal adicional en la forma de planteamiento de un incidente de ejecución (compárese con la BVerfGE 68, $132<141>$ en relación con un recurso de amparo previo)» (§2).

«Siempre y cuando, el legislador dicte una norma con rango de ley que puede ser objeto de un proceso de control de constitucionalidad, queda vedado el camino del incidente de ejecución del § 35 BVerfGG».

«Cosa distinta sucedería si estuviésemos ante un legislador que debiendo hacerlo no tomase medidas, o lo hiciese de tal forma que fuese evidente que materialmente lo hecho resultase equiparable a una inactividad» $(\S 2)$.

A una conclusión muy similar podría llegarse en el caso español. El incidente de ejecución del artículo 92 LOTC no puede convertirse en un remedo de proceso de control de constitucionalidad de las normas con rango de ley alterando sus reglas de legitimación y procedimiento, que son garantía además del complejo equilibrio que debe existir entre la posición constitucional del TC y el legislador democrático.

\section{Conflictos y ejecución}

Han sido muy escasas las ocasiones en las que el TC se ha tenido que plantear un problema de incumplimiento de sus resoluciones recaída en procedimientos conflictuales, ya interorgánicos o territoriales. El artículo 66 LOTC en relación con los conflictos positivos permite al TC acordar «la anulación de la disposición, resolución o actos que originaron el conflicto en cuanto estuvieren viciados de incompetencia, pudiendo disponer lo que fuera procedente respecto de las situaciones de hecho o de derecho creadas al amparo de la misma». El artículo 72,3 LOTC fija el alcance del fallo en los conflictos negativos, en los que o bien declarará improcedente el requerimiento, o procedente, en cuyo caso el TC fijará un plazo «dentro del cual la Comunidad Autónoma deberá ejercitar la atribución requerida ${ }^{39}$. El artículo 75.2 LOTC establece para el caso de los conflictos interorgánicos que «la sentencia del Tribunal determinará a qué órgano corresponden las atribuciones constitucionales controvertidas y declarará nulos los actos

39 Interesantes reflexiones sobre la ejecución en el caso de los conflictos negativos en las pp. 98 y ss. de J. Salas, V. Palomino, ob. cit.

UNED. Teoría y Realidad Constitucional, núm. 38, 2016, pp. 643-682 
ejecutados por invasión de atribuciones y resolverá, en su caso, lo que procediere sobre las situaciones jurídicas producidas al amparo de los mismos».

En la mayoría de las ocasiones los problemas de cumplimiento de las resoluciones del TC recaídas en procesos conflictuales se limitan a dilucidar si se ha estado a la jurisprudencia del TC en relación con la concreta competencia controvertida (como fue el caso de la STC 158/2004 en relación con la doctrina sentada en las SSTC 95 y 190 ambas de 2000 y 230/2003 relativa a la competencia en materia de formación para el empleo). Las pocas ocasiones en las que el TC abordó el alcance efectivo de su fallo fueron resueltas mediante Sentencia y no como un incidente de ejecución, como ocurrió en la STC 65/1984 en relación las competencias autonómicas en materia de registradores de la propiedad; aunque en esta resolución el propio TC señala el incidente del artículo 92 LOTC como el cauce procesal adecuado para resolver cuantas «incidencias» se presentasen al llevar a debido efecto las decisiones del TC sobre las situaciones de hecho o de derecho creadas al amparo de la disposición, resolución o actuación anulada por incompetencia ${ }^{40}$.

\section{LA POSICIÓN DEL TC A TRAVÉS DEL INCIDENTE DE EJECUCIÓN}

Decía Roman Herzog en su «Die Vollstreckung von Entscheidungen des Bundesverfassungsgericht» que sólo era posible alcanzar un juicio objetivo sobre la posición real del TC en el sistema constitucional a partir del grado y la forma en la que sus resoluciones son cumplidas y ejecutadas por los restantes Poderes públicos ${ }^{41}$. El TC en su calidad de «guardián de la Constitución» («Die Hüter der Verfassung»), es también el «dueño de la ejecución» de sus resoluciones («Der Herr der Vollstreckung») ${ }^{42}$. Precisamente el debate constitucional alemán

40 Cuyo FJ 3 sostuvo «En cuanto a las consecuencias derivadas de dicha anulación, es preciso tener en cuenta que, de acuerdo con el art. 66 de la LOTC (LOTC), este Tribunal puede disponer lo que estimare procedente respecto de las situaciones de hecho o de derecho creadas al amparo de la disposición, resolución o acto anulados... En el presente caso, el equilibrio de los intereses en juego aconseja que las situaciones creadas no se destruyan en mayor medida de la que exija la competencia reconocida a la Generalidad. Por lo que se refiere a la situación jurídica de los Registradores afectados, dicho equilibrio, dado el carácter de la competencia estatutaria y el régimen de provisión de vacantes, se logra manteniendo dicha situación, condicionada a la ulterior decisión que la Generalidad de Cataluña adopte en el ejercicio de su competencia. En cualquier caso, las incidencias derivadas de la ejecución de esta Sentencia podrán plantearse ante este Tribunal Constitucional, quien resolverá, en su caso, de conformidad con el art. 92 de la LOTC». Más recientemente, el TC resolvió en efecto un incidente de ejecución en el ATC 177/2012 en relación con la suspensión de una ley autonómica acordada mediante el ATC 105/2010.

41 Herzog, R., «Die Vollstreckung von Entscheidungen des Bundesverfassungsgericht», Der Staat, Bnd. 4 Hft.1, 1965, pp. 37 y ss. Véase también RoTH, W., «Grundlage und Grenzen von Übergangsanordnungen des Bundesverfassungsgerichts zur Bewältigung möglicher Folgeprobleme seiner Entscheidungen», Archiv des öffentlichen Rechts, Bd. 124, 1999, pp. 470 y ss., pp. 475 y ss.; y BETHGE, W., ob. cit., passim. 42 Roth, Wolfgang, ob. cit., pp. 488 y ss. 
sobre los poderes de ejecución del BVerfG estriba en si el alcance de esos poderes en su condición de «dueño de la ejecución» no altera sustancialmente el equilibrio y división de poderes entre los órganos constitucionales, y en particular en su relación con la jurisdicción ordinaria ${ }^{43}$. Un debate aún hoy abierto en la dogmática alemana como pone de manifiesto el comentario al $\S 35$ BVerfGG de Werner Bethge ${ }^{44}$. Sin embargo, quizá debiera enfocarse esta cuestión desde la perspectiva contraria, y preguntarnos sobre si la única forma efectiva de salvaguardar la posición de intérprete y garante supremo de la Constitución del TC no pasa por justamente hacerle «dueño» de la ejecución de sus resoluciones. En el caso de la jurisdicción contencioso-administrativa era evidente que sustraer a la Administración el poder de ejecutar las resoluciones judiciales era una forma indispensable de perfeccionar el Estado de Derecho, y en particular el principio de legalidad, sin que por ello se considere puesta en juego la división de poderes. Otro tanto cabría decir de la jurisdicción constitucional que, en el cumplimiento de su función de garante e intérprete supremo de la CE, debe disponer también del poder de velar por que sus resoluciones se cumplan, que es una forma de asegurar además que se cumple la CE. Cosa distinta es que el TC, al amparo de su competencia sobre la ejecución de sus resoluciones, exceda su ámbito funcional e invada el de otros Poderes del Estado. De ahí la importancia de precisar el objeto y alcance del incidente de ejecución que ni es un proceso de control de constitucionalidad de disposiciones y actos de los Poderes públicos, ni autoriza al TC a realizar por sí lo que a otros les compete por mandato constitucional.

El TC desde sus primeras resoluciones relativas al artículo 92 LOTC ha afirmado rotundo que «En efecto, conforme a la jurisprudencia constitucional (entre otros, AATC 107/2009, de 24 de marzo, FJ 2, y 177/2012, de 2 de octubre, FJ 2) los arts. 87.1 I y 92 LOTC tienen por finalidad garantizar la defensa de la posición institucional del Tribunal Constitucional y la efectividad de sus sentencias y resoluciones, protegiendo su ámbito jurisdiccional frente a cualquier intromisión ulterior de un poder público que pudiera menoscabarla». El TC no ha tenido duda alguna sobre su competencia para cuidar del debido cumplimiento y obser-

43 Véase Bethge, Herbert, ob. cit., pp. 7 y ss., especialmente pp. 9 y ss., donde se advierte del riesgo de convertir el Estado de democrático y de Derecho en un «Estado judicial» («Jurisdiktionsstaates») en virtud de la competencia ilimitada que el $\$ 35$ BVerfGG atribuye al BVerfG en relación con la ejecución de sus resoluciones. Otro tanto cabría decir del artículo 92 LOTC. En España se abrió este debate (incluso premonitorio a la vista de las tensiones que surgieron entre el TC y el TS) — por el TS a cuenta de la ejecución- del TC de una de las sentencias en amparo de aquél — SSTC 115/2000 y 181/2001—; puede encontrarse un relato detallado de este conflicto en Salvador Coderch, P. Gómez Pomar, F. (eds.), Libertad de expresión y conflicto institucional, Civitas, Madrid, 2002, sobre el alcance de la vinculación de la jurisdicción ordinaria a las resoluciones del TC consúltense los trabajos, no siempre coincidentes, De Pérez Tremps, P., Tribunal Contitucional y Poder Judicial, CEC Madrid, 1985; SANTOS Vijande, J., Doctrina y jurisprudencia del Tribunal Constitucional: su eficacia respecto de los Tribunales ordinarios, Comares, Granada, 1995; PunseT, R., «Tribunal Constitucional y órganos judiciales en la tutela de la supremacía de la Constitución. Una perspectiva general», RJA, n. ${ }^{\circ} 19,1995$, pp. 1 y ss., y su «Doctrina constitucional y órganos judiciales», REDC, n. ${ }^{\circ} 46,1996$, pp. 285 y ss.

44 Bethge, W., ob. cit., especialmente pp. 23 y ss. 
vancia de sus resoluciones. El propio ATC 141/2016, y haciendo suya la jurisprudencia continuada y uniforme del TC en este extremo, afirma que le «corresponde a este Tribunal velar por el cumplimiento efectivo de sus Sentencias y resoluciones y resolver las incidencias de ejecución de las mismas, adoptando cuantas medidas considere necesarias para preservar su jurisdicción, incluyendo la declaración de nulidad de aquellos actos y resoluciones que la contravengan o menoscaben» ... «Al margen del principio de presunción de constitucionalidad de las leyes, antes y después de la reforma del marco legal resultante de los arts. 87 y 92 LOTC por la citada Ley Orgánica 15/2015 todos los poderes públicos estaban y están obligados al cumplimiento de lo que resuelva el Tribunal Constitucional y este se hallaba y se halla plenamente facultado para resolver las incidencias de ejecución de sus sentencias y demás resoluciones, pudiendo incluso declarar la nulidad de cualesquiera resoluciones que contravengan las dictadas en el ejercicio de su jurisdicción, con ocasión de la ejecución de estas» (FJ 2).

A nuestro juicio, que el TC cuide del debido cumplimiento de sus resoluciones es lo propio desde el momento que se trata de un órgano que ejerce funciones jurisdiccionales y es a él quien compete ejecutarlas cuando no son cumplidas de oficio o voluntariamente. El artículo 161.1 d) CE da cobertura constitucional suficiente, en nuestra opinión, para que la LOTC regule sus poderes de ejecución. Que así sea perfecciona la posición del TC en el conjunto del sistema constitucional español ${ }^{45}$.

La ejecución en el derecho procesal es una expresión inequívoca de la paz jurídica como concepto nuclear del Estado moderno y del propio Estado de Derecho; esto es, de la imposibilidad de que uno mismo realice por sí su propio derecho. La ejecución de las resoluciones judiciales se manifiesta así como un mecanismo de garantía del monopolio de la fuerza por el Estado, y puede definirse como la imposición forzosa y coactiva de pretensiones de hacer, no hacer o tolerar un comportamiento ${ }^{46}$. La dificultad en el caso de que sea el Estado el sujeto al cumplimiento de una resolución judicial consiste en que es el propio Estado, el cual monopoliza esa fuerza, el que debe obligarse al cumplimiento de las resoluciones judiciales incluso coercitivamente ${ }^{47}$. Históricamente, la inicial tentativa

45 Así lo expresaron Salas, J. Palomino, V., ob. cit., p. 91: «Pues bien, habida cuenta de que la jurisdicción constitucional es una verdadera jurisdicción, en ella se da, por supuesto, la potestad ejecutiva, con todo el haz de facultades inherentes a la misma». En sentido contrario Bocanegra SiERra, R., El valor de las sentencias del tribunal Constitucional, Instituto de Estudios de Administración Local, Madrid, 1982, pp. 55 y ss., y 108 y ss. Véase OtTO y PARdo, I. de, «La posición del Tribunal Constitucional a partir de la doctrina de la interpretación constitucional», El Tribunal Constitucional, IEF, Madrid, 1981.

46 Roth, W., ob. cit., p. 478; Pestalozza, C., Verfassungsprozessrecht, C.H.Beck, Múnchen, 1991 (3. ${ }^{\mathrm{a}}$ edic.), $\$ 19$, rdn. 8

47 Véase Sala, J. Palomino, V., ob. cit., pp. 90 y ss. Geiger identifica la peculiaridad de la jurisdicción constitucional en la circunstancia de que es el propio Estado quien controla su cumplimiento de la norma constitucional, Geiger, W., «Die Grenzen der Bindung verfassungsrechtlicher Entscheidungen ( 31 Abs. 1 BVerfGG)», Neue Juristische Wochenschrift, Hft.29, 1954, pp. 1057 y ss., p. 1058. 
de que el propio Estado condenado se cuidaría de cumplir con lo ordenado en la resolución judicial cedió, como bien se sabe, ante la atribución a la jurisdicción contencioso-administrativa de la potestad de hacer cumplir lo juzgado, además de juzgar, como expresión acabada del Estado de Derecho. No puede ser distinto, ni lo es, el caso de la jurisdicción constitucional habida cuenta de la identidad de razón entre ambas: el control sobre la actividad de los Poderes públicos. Para que ese control sea efectivo, es indispensable que el TC ejecute sus resoluciones y los Poderes públicos las cumplan (incluida la jurisdicción ordinaria) ${ }^{48}$. Cumplir y ejecutar no son, pues, dos nociones distintas y distantes, sino dos funciones atribuidas a órganos distintos, pero con el mismo objeto: asegurar y observar la supremacía normativa de la Constitución. El TC así lo ha entendido incluso en los casos de las resoluciones declarativas ${ }^{49}$.

Obviamente la ejecución es un procedimiento judicial de aplicación de la fuerza coactiva del Estado para asegurar el cumplimiento de sus resoluciones judiciales (y en último término del ordenamiento jurídico). Un procedimiento que en la medida en que dispone del uso de la fuerza se proyectará sobre los sujetos que deben cumplir con lo resuelto y en los términos resueltos judicialmente (que no es más que la expresión para el caso concreto de una regla jurídica, de ahí la conexión con el Estado de Derecho) arbitrando los instrumentos jurídicos y materiales necesarios para que, o bien se ejecute lo ordenado y se haga realidad lo así resuelto, o bien se sustituya si material o legalmente la ejecución en sus propios términos es imposible, so pena de sancionar a quien no lo haga ${ }^{50}$. Así visto, la reforma del artículo 92 LOTC, a pesar de sus deficiencias técnicas, ha fortalecido la posición del TC en el sistema constitucional español precisando el contenido de sus poderes de ejecución y dejando meridianamente claro que los Poderes públicos (y los particulares) cumplen con la CE a través de las resoluciones del TC, y a éste le compete asegurar la supremacía de la CE mediante la ejecución de sus resoluciones si éstas no son cumplidas de oficio o a instancia de parte por el sujeto obligado a hacerlo ${ }^{51}$. Ahora bien, al igual que el $\S 35$ BVerfGG no atribuye al BVerfG un poder ilimitado, tampoco lo hace el artículo 92 LOTC respecto del

48 Véanse Fernández Farreres, G. Sistema de Derecho Administrativo, Civitas, Cizur Menor, 2014, pp. 903 y ss.; BetANCOr RodríGuez, A., «La evolución histórico-normativa de la ejecución de sentencias contencioso-administrativas (1845-1956)», DA, n. ${ }^{\circ} 209,1987$, pp. 199 y ss.

49 Sin perjuicio de que los efectos de la resolución declarativa en algunos casos se agoten con su sola publicación. Un caso de agotamiento de los efectos de la resolución del TC en su fallo puede verse en el ATC 58/2001 en el que el TC desestimó un incidente de ejecución de la STC 231/2000 en estos términos: «Las pretensiones del actor no son viables por cuanto la STC 231/2000 agotó en su fallo cualquier hipotética ejecución: declaró la lesión del derecho fundamental y anuló los Autos judiciales en que aquélla se había producido, de modo que los órganos jurisdiccionales nada tenían que hacer en ejecución de dicha Sentencia, visto que al dictarse ésta, el recurrente estaba ya cumpliendo condena. No puede pretenderse en este impropio incidente de ejecución resolver cuestiones no abordadas ni decididas en el Fallo o con las que éste no guarda una directa e inmediata relación de causalidad» (FJ único).

50 Véase BethGe, W., ob. cit., pp. 11 y ss.

51 Herzog, R., ob. cit., p. 38; Bethge, W., ob. cit., pp. 23 y ss. 
TC. Al TC le compete asegurar la supremacía de la Constitución a través de la ejecución forzosa de sus resoluciones respetando el ámbito propio de responsabilidad que corresponde a los restantes Poderes público de hacer valer también en sus ámbitos competenciales propios esa supremacía ${ }^{52}$. En esa medida, el ATC $141 / 2016$ es respetuoso con este criterio de self-restraint, y recuerda a los destinatarios de su resolución que es a ellos a quienes les cumple en primer término garantizar el respeto a la Constitución en las actuaciones y acuerdos que adopte el órgano que dirigen o presiden.

Queda abierto el debate sobre si la enumeración de medidas del apartado 4 del artículo 92 constituye un elenco cerrado, o es posible que el TC acuda a otros mecanismos de garantía de la efectividad de sus resoluciones. Parece que entre las medidas a las que se refiere el apartado 1 del artículo 92 y la del apartado 4 hay cierta diferencia. Las primeras parecen referirse a las acciones e indicaciones necesarias para el cumplimiento de lo resuelto por el TC y que éste puede disponer en la propia resolución (como cuando ordena el reconocimiento a los recurrentes en amparo de su legitimación activa en el proceso de instancia), donde las posibilidades son múltiples, y llegado el caso se puede acudir a lo dispuesto en la LJCA. En el segundo, la LOTC regula un segundo momento de la ejecución. Precisamente el que se produce tras el incumplimiento de las medidas adoptadas al amparo del artículo 92.1 LOTC por quien estuviere obligado a llevarlas ha debido efecto. Es en ese caso cuando el TC, cumplido el trámite del oportuno incidente, podría acordar éstas del apartado 4 que tienen una finalidad claramente compulsiva. Las primeras son medidas para cumplir lo resuelto, y las segundas lo son para compeler a que se cumpla, incluso apartado a quien debiera hacerlo para atribuir esa función a otro. Justo por esto, por su excepcionalidad, quizá debiera considerarse el apartado 4 como una lista cerrada.

\section{LA CONSTITUCIONALIDAD DE LA REFORMA DEL INCIDENTE DE EJECUCIÓN}

Más arriba hemos mencionado el reproche que le hizo a esta reforma la Proposición de ley para su derogación, y que es probable que sustente también los recursos de inconstitucionalidad interpuestos por los Gobiernos vasco y catalán, revelado quizá en los alegatos de la representación procesal del Parlamento catalán en el ATC 141/2016. Nos referimos a las dudas suscitadas sobre la cobertura constitucional para dotar al TC de semejantes poderes de ejecución. Un debate que también se suscitó con ocasión del § $35 \mathrm{BVerfGG}^{53}$. Los Poderes públicos (y

52 Bethge, W., ob. cit., pp. 15 y ss.

53 Resulta pacífico en la doctrina alemana considerar que la jurisdicción constitucional se extiende no sólo al control de constitucionalidad de disposiciones y actos, también a los poderes necesarios para garantizar el cumplimiento de las resoluciones dictadas en ejercicio de dicha jurisdicción, sin que sea necesaria una ex- 
los particulares) están obligados a cumplir con la CE (artículo 9.1 CE) y con las resoluciones del TC en cuanto expresan la normatividad de los preceptos constitucionales. Y al TC le cumple ejecutarlas si se desatiende esa obligación (164 CE y 87 LOTC). En esa medida, no cabe considerar contraria a la CE la reforma operada de la LOTC. Ni siquiera es necesario que se mencione expresamente en la CE esta potestad de ejecución, porque resulta de la posición constitucional del TC y su función de garante jurisdiccional último de la supremacía constitucional. A nuestro juicio, nada obsta para que esa potestad de ejecución sea considerada una de las «materias» a las que se refiere la letra d) del artículo 161.1 CE y que puede regular la LOTC. La dicción del artículo 161.1 d) CE habilita sin duda al legislador orgánico para regular esta función inherente a la jurisdicción constitucional, máxime cuando en rigor no se trata de regular un nuevo procedimiento de control de constitucionalidad no previsto expresamente en dicho precepto ${ }^{54}$.

Sin embargo, sí que suscita dudas de constitucionalidad la suerte de remoción temporal de su cargo o empleo público de quien, obligado a cumplir con una resolución del TC, no lo ha hecho (artículo 92.4 letra c). Para el caso de los empleados públicos y los cargos públicos en órganos no constitucionales, y regulados por ley ordinaria o disposiciones de rango inferior, lo dispuesto en el artículo 92.4 LOTC constituye una «configuración legal» de su estatuto con arreglo a la garantía que les dispensa el derecho a ocupar y ejercer cargos públicos sin restricciones o perturbaciones ilegítimas del artículo 23 CE. Pero se nos antoja más difícil salvar la tacha de inconstitucionalidad en el caso de que esa suspensión temporal de funciones afecte a miembros y titulares de órganos constitucionales cuyo estatuto jurídico esté reservado expresamente en la CE a una específica ley orgánica reguladora de su estatuto orgánico-funcional (artículo $81 \mathrm{CE}$ ). Otro tanto, creemos, podría decirse de la presidencia de las CCAA y otros titulares de órganos autonómicos cuya regulación está reservada a los EEAA en los términos del artículo $147 \mathrm{CE}$, invadiendo competencias autonómicas por una ley estatal que no es de reforma del EEAA, al fijar causas de cese temporal de sus funciones no previstas en su normativa específica ${ }^{55}$.

presa habilitación de la GG para que la BVerfGG regule esos poderes. Herzog, R., ob. cit., p. 38. BETHGE, W., no pudo ser más contundente: «el $\S 35$ BVerfGG es conforme con la Constitución» (ob. cit., p. 15).

54 Éste fue justamente uno de los reproches que se le hicieron en su momento al control previo de constitucionalidad de normas con rango de ley que preveía originariamente la LOTC, y que ha vuelto a incorporarse para los Estatutos de Autonomía y sus reformas, en la reciente ley de reforma de la LOTC por la LO 12/2015. Sobre esta cuestión véase Villaverde MenÉndeZ, I., «El control previo de constitucionalidad de las normas con rango de ley. Crónica de un escéptico», Revista Catalana de Derecho Público, n. o 49, 2014, pp. 20 y ss., pp. 37 y ss.

55 No debe confundirse la previsión del artículo 92.4 LOTC con los procedimientos constitucionales de remoción del Jefe del Estado que se deben seguir ante el correspondiente Tribunal Constitucional, como es el caso alemán, italiano o austriaco. El artículo 61 de la Ley Fundamental de Bonn (en adelante, LFB) prevé un procedimiento de remoción del Presidente de la República ante el BVerfG que no está previsto sin embargo en la CE. Este precepto regula un procedimiento a instancia del Bundestag o del Bundesrat de destitución del Presidente de la República en caso de que éste vulnere deliberadamente la LFB o cualquier otra Ley fede- 
TITLE: The enforcement powers of the resolutions of the Constitutional Court and its recent reform

ABSTRACT: This article analyzes the recent reform of the Organic Law of the Constitutional Court (LOTC) to strengthen the enforcement powers of the resolutions by the Constitutional Court. The author examines the origin of the reform, its content, the enforcement procedure and the doctrine of the Constitutional Court on the matter. Likewise, the Resolution of the Constitutional Court 141/2016 in which the Court has had the first opportunity to apply Article 92 LOTC after its reform. The author's thesis is that the reform has clarified and improved LOTC enforcement proceedings TC resolutions, providing the TC specific powers to ensure compliance its resolutions by public authorities and individuals. However, the author draws attention to the questions of constitutionality which raise some of the implementing measures provided for in Article 92 LOTC as the temporary suspension of public office in constitutional or regional public Institutions.

Resumen: Este artículo analiza la reciente reforma de la Ley Orgánica del Tribunal Constitucional (LOTC) para reforzar los poderes de ejecución de sus resoluciones. Examina el origen de la reforma, su contenido, el procedimiento de ejecución y la doctrina del Tribunal Constitucional sobre la materia. Igualmente se analiza el Auto del Tribunal Constitucional 141/2016 en el que el Tribunal ha tenido la primera ocasión de aplicar el artículo 92 LOTC tras su reforma. La tesis del autor es que la reforma de la LOTC ha precisado y mejorado el procedimiento de ejecución de sus resoluciones, dotando al TC de poderes concretos dirigidos a asegurar su cumplimiento por los poderes públicos y los particulares. No obstante, el autor llama la atención sobre las dudas de constitucionalidad que suscitan alguna de las medidas de ejecución establecidas en el articulo 92 LOTC, como la suspensión temporal de cargos públicos en órganos constitucionales o autonómicos.

KeY words: Constitutional jurisdiction. Constitutional Court. Enforcement Constitutional Court Resolutions. Implementation of Constitutional Court Resolutions.

Palabras Clave: Jurisdicción constitucional. Tribunal Constitucional. Incidente de ejecución. Vinculación de las resoluciones del Tribunal Constitucional.

FECHA DE RECEPCIÓN: 22.07.2016 FECHA DE ACEPTACIÓN: 01.09.2016

ral. El BVerfG, que nunca se ha visto en tal tesitura, tras un breve proceso regulado en los \$\$ 49-57 BVerfGG, podrá declarar que el Presidente de la Federación es culpable de vulnerar deliberadamente la LFB o cualquier Ley federal por lo que «puede» removerlo del cargo. Incluso el propio precepto apodera al BVerfG para adoptar como medida cautelar una vez admitida a trámite la demanda su suspensión en el ejercicio de su cargo. Obviamente no es el caso del artículo 92.4 LOTC, ya que no se trata de un incidente de ejecución. También el artículo 134 de la Constitución italiana atribuye a la Corte Constitucional la competencia para conocer de las acusaciones contra el Presidente de la República por vulneración de la Constitución. Lo mismo sucede en Austria, cuya Ley reguladora del Tribunal Constitucional austriaco (B-VG) en sus artículos 142 y ss., que amplía la competencia para conocer también de acusaciones dirigidas contra los miembros de los órganos superiores federales y de los Estados federados. En el caso del Presidente de la República, sólo si lo vulnerado es la Constitución. Los miembros del Gobierno federal, Presidentes de los Estados federados y miembros de sus Gobiernos y otros altos cargos del Estado también pueden serlo por vulneración de las leyes federales. 